\title{
The role of interleukin-1 in general pathology
}

\author{
Naoe Kaneko, Mie Kurata, Toshihiro Yamamoto, Shinnosuke Morikawa and Junya Masumoto ${ }^{*}$ (D
}

\begin{abstract}
Interleukin-1, an inflammatory cytokine, is considered to have diverse physiological functions and pathological significances and play an important role in health and disease. In this decade, interleukin-1 family members have been expanding and evidence is accumulating that highlights the importance of interleukin-1 in linking innate immunity with a broad spectrum of diseases beyond inflammatory diseases. In this review, we look back on the definition of "inflammation" in traditional general pathology and discuss new insights into interleukin-1 in view of its history and the molecular bases of diseases, as well as current progress in therapeutics.
\end{abstract}

Keywords: Interleukin-1, Metabolic inflammation, Inflammatory diseases, Cancer, Drug target

\section{Background}

In terms of general pathology, inflammation is one of the adaptive responses to various injuries including physical, chemical, and biological factors. The Roman encyclopedist A. Cornelius Celsus described four cardinal signs of inflammation in one concise sentence: "Now the signs of an inflammation are four: redness (rubour) and swelling (tumour), with heat (calour) and pain (dolour)" [1]. A century and a half later, Galen added a fifth sign: "disturbance of function" (funcio laesa) [2]. The classical signs of inflammation are considered to be related to cells and tissues responding to pathological cell injury caused by internal stimuli, including damage-associated products and metabolites, and external stimuli, including bacteria and viruses [3-6].

The host bears the receptors that facilitate recognition of these damage-associated molecular patterns (DAMPs) and/ or pathogen-associated molecular patterns (PAMPs) that are not host-derived. These receptors are termed pattern recognition receptors (PRRs) [7]. PRRs directly or indirectly detect infection and/or noxious chemicals, resulting in inflammation that is coupled with the induction of immune responses and a tissue reparative component [8]. The signal transduction triggered by these PRRs leads to the acute inflammatory mediator expressions that regulate the elimination of pathogens and infected cells $[9,10]$.

\footnotetext{
* Correspondence: masumoto@m.ehime-u.ac.jp

Department of Pathology, Ehime University Graduate School of Medicine and Proteo-Science Center, Shitsukawa 454, Toon, Ehime 791-0295, Japan
}

There are several known PRRs: Toll-like receptors (TLRs), RIG-I-like receptors (RLRs), NOD-like receptors (NLRs), and C-type lectin receptors (CLRs). The majority of NOD-like receptors such as NLRP1, NLRP3, NLRC4, NLRP6, and NLRP12 can interact with apoptosis-associated speck-like protein containing a caspase-recruitment domain (ASC) and caspase- 1 , and the resulting complex is a sensor of cell injury called "inflammasome", an interleukin (IL)-1 $\beta$-processing platform that plays a crucial role in IL-1 $\beta$ maturation and secretion from cells. Other pyrin-domain (PYD)-containing proteins such as AIM2, IFI-16, and pyrin are also known to form inflammasomes. Among them, NLRP3 inflammasomes monitor membrane integrity and pore-forming toxins, crystals, and many other noxious stimuli and are involved in IL-1 $\beta$ processing and maturation [11-14]. It is now widely accepted that an inflammatory response is the extreme end of a spectrum that ranges from a homeostatic state of inflammation to a stress response and finally inflammation $[8,15]$. The homeostatic state of inflammation, which is not inflammation from the perspective of general pathology, was suggested to be maintained by PRRs expressed in stromal and/or immune cells, detecting endogenous ligands in parenchymal cells and/or pathogens, leading to chronic inflammatory responses ranging from the basal homeostatic state to disease-causing inflammation $[15,16]$. In addition to several forms of inflammation including classical inflammation, homeostatic inflammation, a distinct nomenclature for low-grade inflammation, such as

(c) The Author(s). 2019 Open Access This article is distributed under the terms of the Creative Commons Attribution 4.0 International License (http://creativecommons.org/licenses/by/4.0/), which permits unrestricted use, distribution, and reproduction in any medium, provided you give appropriate credit to the original author(s) and the source, provide a link to the Creative Commons license, and indicate if changes were made. The Creative Commons Public Domain Dedication waiver (http://creativecommons.org/publicdomain/zero/1.0/) applies to the data made available in this article, unless otherwise stated. 
para-inflammation (an adaptive response against stress or malfunction) and meta-inflammation (metabolically triggered inflammation), has been proposed [17-19]. As discussed above, there are various factors involved in forms of inflammation; in particular, since IL-1 is a downstream cytokine of the sensor of cell injury, the inflammasome, it is important for regulating inflammation and tissue damage beyond inflammation [20].

\section{Biological functions of interleukin-1}

IL-1 is a master regulator of inflammation via controlling a variety of innate immune processes [21]. From a historical point of view, IL-1 has a wide range of biological functions, which include acting as a leukocytic pyrogen, a mediator of fever and a leukocytic endogenous mediator, and an inducer of several components of the acute-phase response and lymphocyte-activating factor (LAF) [22, 23]. LAF was later shown to be a macrophage-derived immune mediator acting on T- and B- lymphocytes and was designated as IL-1 in the Second International Lymphokine Workshop held in Switzerland in 1979 [24, 25]. In addition, serum blocking factors in breast cancer patients identified by the leukocyte adherence inhibition test were reported. The serum adherence-promoting factors were regulated by IL-1 [26-28]. To date, the tumor microenvironment has been characterized by dominant immunosuppression, being infiltrated by tumor immunosuppressive myeloid-derived suppressor cells (MDSCs), regulatory $\mathrm{T}$ cells (Tregs), and tumor-associated macrophages (TAMs) $[29,30]$. IL-1 is capable of inducing the recruitment of TAMs and MDSCs, which promote tumor development in breast cancer [31].

\section{Interleukin-1 family members}

Currently, human sequence algorithm technologies suggest that the IL-1 family comprises a total of 11 members with similar or distinct biological effects [32, 33]. IL-1 $\alpha$, IL-1 $\beta$, IL-1Ra, IL-18, IL-33, IL-36 $\alpha$, IL-36 $\beta$, IL-36y, IL-36Ra IL-37, and IL-38 have been identified and characterized (Table 1) [32]. Among them, IL-1 $\alpha$, IL-1 $\beta$, IL-18, IL-33, and IL-36 are receptor-agonistic, and IL-1Ra, IL-36Ra, and IL-38 are receptor-antagonistic. IL-37 is the only anti-inflammatory cytokine. Although the function of each IL-1 family member is now being investigated, IL-1 is the most characterized among these members.

\section{Molecular mechanism of interleukin-1 activation}

There are two individual forms of IL-1, IL- $1 \alpha$ and IL-1 $\beta$, isolated from two distinct cDNAs, but they are indistinguishable in terms of their biological functions [34]. Although the homology between IL- $1 \alpha$ and IL-1 $\beta$ is not high $(27 \%)$ in terms of amino acid sequences, IL-1 $\alpha$ and IL-1 $\beta$ are structurally similar and show the same functions by sharing a common receptor, IL-1 type 1 receptor
Table 1 The IL-1 family members

\begin{tabular}{lll}
\hline IL-1 family members & Receptor & \multicolumn{1}{c}{ Property } \\
\hline IL-1a & IL-1RI & Inflammatory \\
IL-1 $\beta$ & $|L-1 R|$ & Inflammatory \\
IL-1Ra & IL-1RI & IL-1RI antagonist \\
IL-18 & IL-18Ra & Inflammatory \\
IL-33 & ST2 & Th2 inflammation \\
IL-36Ra & IL-1Rrp2 & IL-1Rrp2 antagonist \\
IL-36a & IL-1Rrp2 & Inflammatory \\
IL-36ß & IL-1Rrp2 & Inflammatory \\
IL-36y & IL-1Rrp2 & Inflammatory \\
IL-37 & IL-18Ra & Anti-inflammatory \\
IL-38 & IL-1Rrp2 & IL-1Rrp2 antagonist \\
\hline
\end{tabular}

(IL-1R1), and both have the same central $\beta$-barrel along with adjoining loops $[35,36]$. The difference between IL-1 $\alpha$ and IL- $1 \beta$ is an N-terminal extension of 14 residues beyond the N-terminus of IL- $1 \alpha$ and IL-1 $\beta$ [37]. The molecular weight of each precursor is approximately $31 \mathrm{kDa}$, and IL- $1 \alpha$ and IL- $1 \beta$ are processed by specific proteases to mature forms. The N-terminal domain of IL- $1 \alpha$ contains a nuclear localization sequence (NLS) and shows transcription activity [38]. IL-1 $\alpha$ is produced as a 271 -amino acid (AA) precursor protein. For transcription of the IL- $1 \alpha$ gene, transcription factor specificity protein $1(\mathrm{Sp} 1)$ activates the IL-1 $\alpha$ promoter activity in the $5^{\prime}$-upstream GC box $(-60$ to $-45 \mathrm{bp}$ ) [39] and NF-kB, which is also activated by IL-1 $\alpha$ itself, and stimulates the consensus promoter region ( -103 to $-70 \mathrm{bp})$ to induce its own gene expression and production in an autocrine manner [40]. The precursor of IL- $1 \alpha$ translocates into the nucleus to bind to chromatin and also exists in a membrane-anchored form. Upon stress responses, IL- $1 \alpha$ is processed by $\mathrm{Ca}^{2+}$-dependent protease calpain or other proteases, such as cytotoxic T- lymphocytes (CTL)/natural killer (NK)-granzyme-B, mast cell chymase, or neutrophil elastase to the C-terminal 159 AA as mature IL- $1 \alpha$ [41]. The IL-1 $\alpha$ processing separates NLS from its precursor, which is not linked to secretion or cell death [21]; however, IL-1 $\alpha$ is a key danger signal that induces inflammation on release from necrotic cells [42]. The IL- $1 \alpha$ precursor triggers IL-1R1 on resident macrophages in necrotic tissues, producing IL- $1 \beta$ as well as chemokines as post-necrotic inflammation [43].

IL-1 $\beta$ is produced as a 269-AA precursor protein and processed by caspase- 1 , which is also known as IL- $1 \beta$-converting enzyme (ICE), activated in inflammasomes, to the C-terminal $153 \mathrm{AA}$ as mature IL- $1 \beta[11,12,34,44]$. The IL-1 $\beta$ precursor is also processed by other serine proteases [45]. Neutrophils derived from caspase-1-deficient mice release mature IL-1 $\beta$ processed by elastase in response to lipopolysaccharide (LPS) stimulation [46]. The neutrophil proteases, such as elastase, chymases, granzyme A, 
cathepsin $\mathrm{G}$, and proteinase- 3 , cleave the IL- $1 \beta$ precursor into a secreted, biologically active form [47-49]. These alternatively cleaved forms of functional IL- $1 \beta$ were detected in synovial fluid of a patient with inflammatory polyarthritis and gout [50]. Occasionally, massive neutrophil infiltration appeared in excess-inflammation-damaged tissues and organs, such as in septic shock or systemic inflammatory response syndrome. Thus, the NLRP3 inflammasome-related inflammation induced by a variety of factors described above may be a target of anti-IL-1 therapy [51].

Currently, a two-step model of the initiation of NLRP3 inflammasome activation is suggested. The first step mediates transcriptional and post-translational priming of NLRP3 (Step1), and the second step is activation of inflammasomes (Step 2). Step 1 is the first synthesis of a biologically inactive IL- $1 \beta$ precursor by NF- $\mathrm{kB}$ binding to the consensus binding site ( -296 to $-286 \mathrm{bp}$ ) to transcribe the IL-1 $\beta$ gene. Step 2 is processing into mature, biologically active IL- $1 \beta$ by caspase- 1 activated by a cytosolic activation platform called inflammasome [52, 53]. The inflammasome is a large protein complex, which consists of PRRs, such as NLRs, AIM2, RIG-I or pyrin, an adaptor protein ASC, and caspase-1. Among them, the NLRP3 inflammasome is a prototype inflammasome, which has been reported to be activated by a wide range of PAMPs and DAMPs [54, 55]. Various NLRP3-activating PAMPs have been reported, i.e., bacteria-derived RNA or DNA, pore-forming toxins, lethal toxins, flagellin/rod proteins, muramyl dipeptide (MDP), M2 protein, virus-derived RNA or DNA, fungus-derived $\beta$-glucans, hypha mannan, zymosan, and protozoon-derived hemozoin [56]. NLRP3-activating DAMPs have also been reported, i.e., self-derived glucose, $\beta$-amyloid, hyaluronan, ATP, cholesterol crystals, monosodium urate (MSU) crystals, calcium pyrophosphate dihydrate (CPPD) crystals, environment-derived alum, asbestos, silica, alloy particles, UV radiation, and skin irritants [56]; however, their diverse physiological and chemical signals leading to the direct activation of NLRP3 have not been fully elucidated. Instead, efflux of potassium has been identified as the common activator of most known NLRP3 step 2 signals $[57,58]$. The NLRP3 activation by potassium efflux suggested to lead NLRP3-Nek7 interaction to drive inflammasome activation [59-61]. The mechanism underlying the secretion of IL-1 $\beta$ has been suggested to overlap with IL-1 $\alpha$ secretion [41]. Also, mitochondrial and phagosomal reactive oxygen species (ROS) have been proposed to activate the NLRP3 inflammasome. Alternatively, non-canonical pathways of NLRP3-inflammasome activation associated with proinflammatory caspases, caspase- 4 , caspase- 5 , and caspase- 11 have been proposed. In this process, LPS is recognized by the caspase-recruitment domain (CARD) of respective caspases, leading to activation [62-65]. Caspase- 8 or proteases in neutrophils are also processed and activate IL-1 $\beta$. Several PRRs, such as NLRP1, NLRP3, NLRC4, pyrin, and AIM2, convert the assembly of the adaptor molecule ASC into a high-molecular-weight complex, called the pyroptosome [66]. Then, the caspase- 1 precursor is recruited to the pyroptosome to also form helical structures, which enable its proximity-induced proteolytical auto-activation. With caspase-1 precursor maturation into the active p102/p202 heterotetramer, it cleaves the IL- $1 \beta$ precursor, leading to pyroptotic cell death. This cell death is mediated by the caspase-1-dependent cleavage of gasdermin-D (GSDMD) [67-69]. In turn, the mature $\mathrm{N}$-terminal fragment of GSDMD translocates to the inner leaflet of the plasma membrane to form round and pore-like structures of approximately $15 \mathrm{~nm}$ in diameter [70-73].

\section{Tissue distributions of interleukin-1}

IL- $1 \alpha$ and IL-1 $\beta$ are expressed in a wide range of tissues and a variety of cells, especially in macrophages in lymphoid organs including the thymus, spleen, lymph nodes, Peyer's patches, and bone marrow. In non-lymphoid organs, IL- $1 \alpha$ and IL- $1 \beta$ are expressed in tissue macrophages in the lung, digestive tract, and liver. They are also expressed in cellular subepithelial endometrial tissue of the uterus, in the glomeruli, in outer cortical areas of the kidney, and in various specific cell types, including neutrophils, keratinocytes, epithelial and endothelial cells, lymphocytes, smooth muscle cells, and fibroblasts [74, 75].

\section{Interleukin-1 receptors and subcellular signaling}

There are two cell surface IL-1 receptors, IL-1R1 and IL-1 type 2 receptor (IL-1R2), a decoy receptor. IL-1 binds to IL-1R1, which requires the formation of a heterodimer with the IL-1 type 3 receptor (IL-1R3) (also known as IL-1RAcP) accompanied by adaptor IL-1 receptor-associated kinase (IRAK) and myeloid differentiation primary response protein 88 (MyD88) [76]. IL-1R1 initiates inflammatory responses when binding to the ligands IL- $1 \alpha$ and IL-1 $\beta$ and has been reported to be expressed by Tlymphocytes, fibroblasts, epithelial cells, and endothelial cells. IL-1R2, which does not initiate signal transduction, is expressed in a variety of hematopoietic cells, especially in B- lymphocytes, mononuclear phagocytes, polymorphonuclear leukocytes, and bone marrow cells. Notably, expression levels of IL-1R1 and IL-1R2 are different among the cell types; for example, neutrophils predominantly express IL-1R2. As a result, much higher concentrations of IL-1 $\beta$ are required to activate neutrophils, whereas low concentrations of IL-1 $\beta$ are sufficient to activate endothelial cells. The IL-1R1-mediated signaling pathways also differ according to the cell types [77, 78]. IL-1R3 is a co-receptor for IL-1R1, responsible for signaling after binding ligands IL- $1 \alpha$ and IL-1 $\beta$, and has been reported to be ubiquitously expressed by all cells responsive to IL-1. IL-1R3b is a brain-specific isoform of IL-1R3 generated by alternative 
splicing, and it has been reported to be expressed in the brain, cerebellum, and spinal cord [79].

Activated IL-1 is incapable of functioning until recognized by cell surface receptors. The complex contains a motif of GTPase activity and activates GTPase-activating protein and protein kinases [80-82]. In contrast, IL-1R2 is thought to reduce the biological response to IL-1. The proximity of the two cytoplasmic domains of IL-1R1 and IL-1R3 is thought to initiate signal transduction by the hydrolysis of GTP. This is followed by c-Jun N-terminal kinase (JNK) and p38 MAP kinase [83]. IRAK and tumor necrosis factor (TNF) receptor-associated factor (TRAF) 6 activate NF- $\mathrm{kB}$, as well as p38, JNKs, extracellular signal-regulated kinases (ERKs), and mitogen-activated protein kinases (MAPKs) [84]. The $\mathrm{NF}-\mathrm{kB}$ activation pathway is dependent on the IK-B kinase (IKK) complex, composed of IKK $\alpha$, IKK $\beta$, and NF- $\mathrm{BB}$ essential modulator (NEMO), via associations with TAK1, TAK2, TRAF2, and TRAF6 in the IL-1R1-signaling pathway [85]. These signals play important roles in both acute and chronic inflammation in various diseases [86].

\section{Interleukin-1 and diseases \\ Autoinflammatory diseases}

Single nucleotide mutation of the CIAS1 gene results in NLRP3 mutation, which induces constituted inflammasome activation causing cryopyrin-associated periodic syndrome (CAPS). This is termed autoinflammatory disease, including familial cold autoinflammatory syndrome (FCAS), MuckleWells syndrome (MWS), and neonatal-onset multisystem inflammatory disease (NOMID)/chronic infantile neurologic, cutaneous, and arthritis (CINCA) syndrome, which leads to greater IL-1 $\beta$ secretion without any DAMPs or PAMPs [87-92]. The most common autoinflammatory disease is Familial Mediterranean fever (FMF). FMF is autosomal recessive; however, mutations in the causative $M E F V$ gene, encoding mutated pyrin, leads to active pyrin inflammasome [93]. Inflammatory diseases like those above, characterized by the enhanced secretion of IL-1 $\beta$, include a group of autoinflammatory diseases such as NLRP12 autoinflammatory syndrome; hyperimmunoglobulinemia $\mathrm{D}$ and periodic fever syndrome (HIDS)/mevalonate kinase deficiency (MKD); pyogenic arthritis, pyoderma gangrenosum, and acne (PAPA) syndrome; pyoderma gangrenosum, acne, and suppurative hidradenitis (PASH) syndrome; pyogenic arthritis, acne, pyoderma gangrenosum, and suppurative hidradenitis (PAPASH); Majeed syndrome; and TNF-receptor-1-associated syndrome (TRAPS) [93-100]. On deficiency of the IL-1-receptor antagonist (DIRA), excess IL-1 $\beta$ induces other proinflammatory cytokines and chemokines [101].

\section{Metabolic syndromes}

Excess stress responses disrupt body homeostasis under physiological conditions and lead to excess cytokine production. NLRP3 inflammasomes have also been reported to be involved in low-grade subclinical inflammation induced by chronic exposure to high levels of free fatty acids and glucose, leading to increased apoptosis and impaired insulin secretion of $\beta$-cells in obese type 2 diabetes mellitus (T2D) patients [102-104]. Indeed, islet amyloid polypeptide (IAPP) oligomers activated NLRP3 inflammasomes to induce significant IL- $1 \beta$ production by infiltrating macrophages in an in vivo study $[105,106]$. Higher concentrations of glucose activate NF- $\mathrm{kB}$ and IL-1 precursors in cells [102]. Minimally oxidized low-density lipoproteins stimulate TLR4, which triggers IL-1 $\beta$ expression $[104,105]$, and accumulations of islet amyloid polypeptides are deposited and mediate NLRP3 inflammasome activation in islet macrophages [107]. Another oligomer of amyloid, amyloid $\beta$, can induce IL-1 $\beta$ via NLRP3 inflammasomes in a process involving the phagocytosis of amyloid $\beta$ in glial cells in patients with Alzheimer's disease (AD) and subsequent lysosomal damage and release of cathepsin B [108]. ROS are considered to be involved in the activation of NLRP3 inflammasomes, and it was suggested that direct interaction between amyloidogenic peptide and NLRP3 could initiate NLRP3 inflammasome formation in a cell-free system [109, $110]$. Both IL- $1 \alpha$ and IL- $1 \beta$ gene polymorphisms have been reported to be associated with central obesity and metabolic syndrome in a population with coronary heart disease in an epidemiologic study [111]. Thus, these diseases are IL-1dependent cytokinopathies (interleukinoneopathies).

\section{Acute inflammation}

Besides the above diseases, numerous inflammatory diseases related to excess IL-1 signaling have also been identified [112-114]. For example, high IL-1 $\beta$ levels in humans and mice result in increased Th17-dominant immunopathology, and IL-1 $\beta$ expression was limited to macrophages and neutrophils, which account for a large proportion of the CD $45 \alpha$ cells in the cervix upon Chlamydia muridarum infection [115]. Consequently, IL-1 $\beta$ promotes the differentiation of monocytes into conventional dendritic cells (DCs) and M1-like macrophages and supports the proliferation of activated B- lymphocytes and their differentiation into plasma cells [116-118]. IL-1 in combination with IL-2 promoted not only the expansion of NK cells but also CD4+ CD8+ T-lymphocytes [119]. IL-1 $\beta$ generated by activated antigen-presenting cells (APCs) induced type $1 \mathrm{im}$ mune responses, which produced CTL and led to the polarization of CD4+ T-lymphocytes towards T-helper cell type 1 (Th1) [120, 121].

\section{Chronic inflammation and malignancy}

IL-1 $\beta$ plays a role in resolving acute inflammation resulting in the initiation of adaptive anti-tumor responses; however, chronic inflammatory conditions increase the risk of developing cancer [122]. In human breast cancer, higher 
expression of IL- $1 \beta$ is associated with tumor invasiveness and aggressive tumor biology [123]. Expression of IL-1 $\alpha$, IL-1 $\beta$, and their receptors in human breast cancer tissues results in the activation of a population of cells and subsequently contributes to angiogenesis, tumor proliferation, and tumor invasion in the microenvironment [124]. In a spontaneous MMTV-PyMT mouse mammary gland tumor model, mature IL-1 $\beta$ levels in primary mammary tumors and metastasis sites were significantly elevated, being associated with inflammasome activation and the infiltration of myeloid cells in tumor microenvironments. In this model, $\mathrm{CD}_{11 b^{+}} \mathrm{Gr}^{+}$and $\mathrm{CD}^{+} 1 \mathrm{~b}^{+} \mathrm{Gr} 1^{-}$myeloid cell populations were also significantly increased in both tumor tissues [31]. IL-1 $\beta$ generated in a tissue with a tumor microenvironment dominated by TAMs promotes tumor growth and metastasis in breast cancer $[122,125]$. IL-1, by promoting MDSCs and sustaining the immunosuppressive activity of TAMs, contributes to the suppression of effective adaptive anti-tumor immune responses [126]. Actually, the sphingolipid sphingosine-1-phosphate (S1P) on TAMs promotes lymphangiogenesis and lung metastasis via NLRP3/IL-1 $\beta$ in mouse breast cancer model [127]. For example, obesity induces an increase in tumor-infiltrating MDSCs with activated NLRC4 inflammasome, leading to IL-1 $\beta$ production, which drives tumor progression through adipocyte-mediated vascular endothelial growth factor (VEGF) A expression and angiogenesis [128]. A recent report showed that IL-1 $\beta$ orchestrates tumor-promoting inflammation in patients with high-risk HER2-negative breast cancer who would benefit from IL-1-blocking therapeutics with anakinra (described later on). The report indicates that while anakinra downregulates gene expressions for IL-1 $\beta$, IL-1R1, IL-1R2, and IL-1R3, increased gene expressions of NK cells and CTLs are observed [129].

\section{Interleukin-18 and diseases}

Although IL-1 has been well-characterized, IL-18 and other IL-1 family members have been less comprehensively investigated. IL-18 can be processed by caspase- 1 and proteinase-3 as well as IL-1 $\beta$, to be activated [130-132]. Considering the pathogenesis of IL-1-related diseases, IL-18 could be involved [133].

IL-18 was originally identified as interferon (IFN)- $\gamma$-inducing factor [134]. IL-18 is the most structurally related to IL-1 $\beta$. IL-18 is synthesized as a $24-\mathrm{kDa}$ inactivated precursor and is cleaved by caspase- 1 to a biologically active $17-\mathrm{kDa}$ mature form $[131,132]$. Although IL-1 $\beta$ is biologically active within the $\mathrm{pg} / \mathrm{mL}$ range, IL-18 requires $10-20$ $\mathrm{ng} / \mathrm{mL}$ and sometimes higher levels for in vitro activation $[135,136]$. Since the IL-18 precursor is expressed ubiquitously in tissues [137], IL-18 signaling is thought to be regulated concentration-dependently. Mature IL-18 forms a signaling complex with the IL-18 receptor alpha chain (IL-18R $\alpha$ ) with low affinity. If the cell expresses an IL-18 receptor $\beta$ chain (IL-18R $\beta$ ), a high affinity complex is formed like the IL-1R accessory chain IL-1R3. The complex of the heterodimer recruits MyD88 through the Toll-IL-1 receptor (TIR), four IRAKs, and TRAF-6, leading to the degradation of $\mathrm{I}-\mathrm{kB}$ and activation of NF- $\mathrm{kB}$, as that for IL-1 signaling [83].

IL-18 is involved in regulation of the Th1 response by modulating the production of IFN- $\gamma$. For example, in synergy with either IL-12 or IL-15, which upregulates the expression of the IL-18R $\beta$ co-receptor, IL-18 induces the production of IFN- $\gamma$ by T cells [138]. IL-18 induces IFN- $\gamma$ production by NK cells, and NK cells express CCR7 and produce high levels of IFN- $\gamma$ [139]. The combination of IL-18 and IL-12 induced high levels of IFN- $\gamma$ upon hypoglycemia, intestinal inflammation, and inanition [140]. Some human autoimmune diseases are associated with the elevated production of IFN- $\gamma$ and IL-18. Autoimmune diseases such as systemic lupus erythematosus, rheumatoid arthritis (RA), type-1 diabetes mellitus, Crohn's disease and psoriasis, and graft versus host disease are thought to be mediated by IL-18 [141]. So far, several anti-IL-18 therapies have been reported. An anti-IL-18, multicenter, randomized, single-blind, placebo-controlled, parallel-group, phase IIa trial for the treatment of T2D was reported whereby anti-IL-18 monoclonal antibody, GSK1070806, was well-tolerated; however, the anti-IL-18 therapy did not lead to any improvements in glucose control [142]. Interleukin18 binding protein (IL-18BP) was purified from urine by chromatography on IL-18 beads that abolished IL-18 induction of IFN- $\gamma$, IL-8, and activation of NF- $\kappa$ B in vitro [143]. The IL-18 inhibition using IL-18BP significantly decreased MDSCs in the tumor microenvironment in a preclinical osteosarcoma mouse model [144]. IL-18BP (Tadekinig $\alpha^{\circledast}$ ) was successful in the treatment of Still's disease and NLRC4-mutated autoinflammatory macrophage activation syndrome (MAS), for which anti-IL-1 treatment had failed $[145,146]$.

\section{Biologics against interleukin-1 signaling and their applications}

Several inhibitors of IL-1 signaling have been clinically approved (Fig. 1).

\section{Anakinra}

One is a recombinant human intrinsic IL-1 receptor antagonist (IL-1Ra), anakinra [147]. Anakinra is the pharmaceutical name of a recombinant form of intrinsic human IL-1Ra, a 17.2-kDa protein consisting of 153 amino acid residues. IL-1Ra was first reported in 1985 as a bioactive IL-1 inhibitor of $22-25 \mathrm{kDa}$ in the supernatants of human monocyte culture, and it was independently identified as an IL-1 inhibitor from the urine of febrile patients [148, 149]. Anakinra was the first biological drug of a selective IL-1R1 antagonist to receive approval from the US Food and Drug 


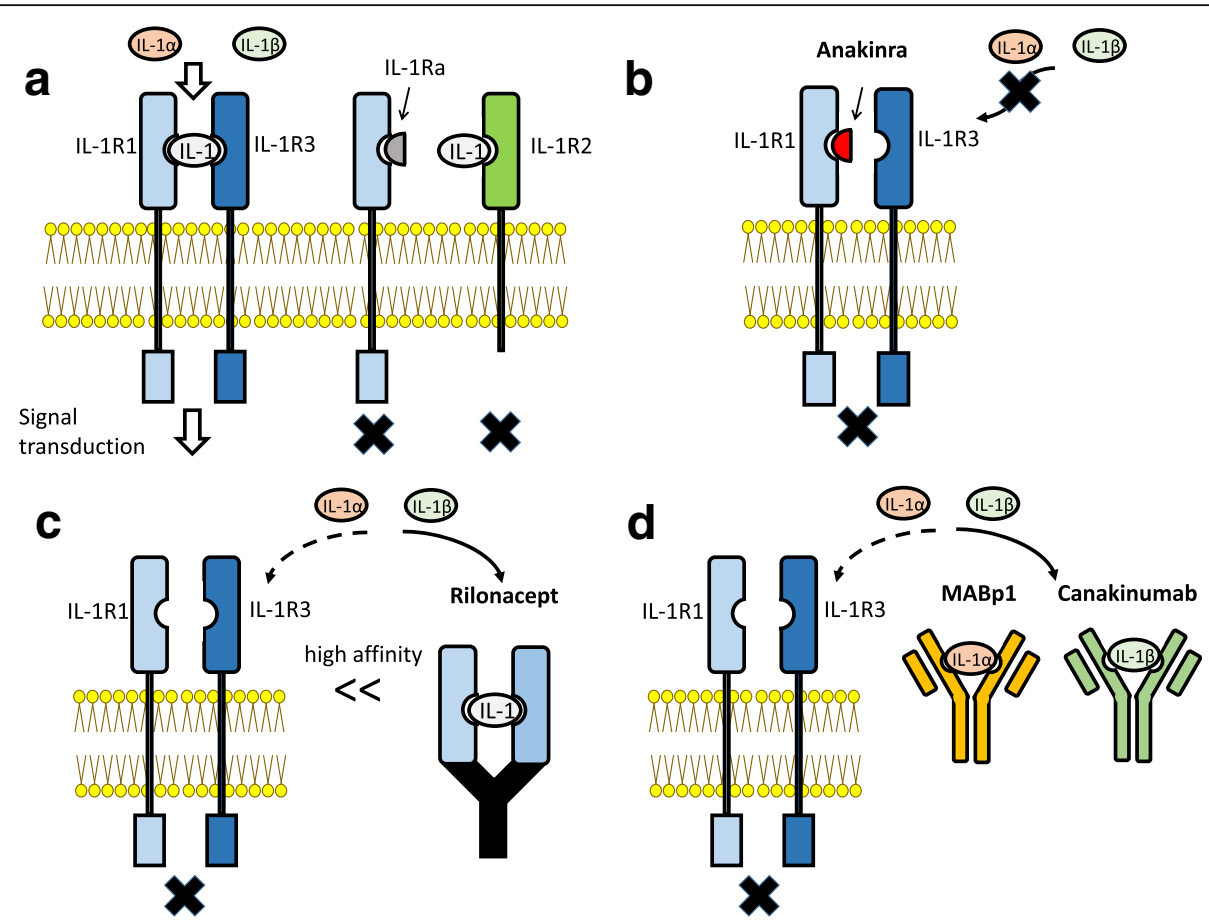

Fig. 1 Interleukin-1 receptors and inhibitors of IL-1 signaling. a IL-1R1 interacts with both IL-1a and IL-1 $\beta$ and promotes signal transduction, together with its co-receptor IL-1R3 (IL-1RAcP). IL-1Ra is a protein that binds to IL-1R1 but not IL-1R3, and it is as an inhibitor of IL-1 signaling. IL-1R2 is a decoy receptor because it lacks a cytoplasmic segment. $\mathbf{b}$ Anakinra is a recombinant form of intrinsic human IL-1Ra. It works as an antagonist of IL-1R1, and it is able to inhibit both IL-1 $a$ and IL-1 3 . c Rilonacept is a recombinant fusion protein including the extracellular protein of human IL-1R1 and IL-1R3 fused with the Fc portion of human IgG1. It binds to both IL-1 1 and IL-1 $\beta$ with high affinity and has a long-term inhibitory effect. $\mathbf{d}$ Canakinumab and MABp1 are monoclonal antibodies against IL-1 $\beta$ and IL-1a, respectively. They bind to and neutralize their targets specifically

Administration (FDA). Since anakinra is an IL-1 receptor antagonist, it can prevent the activity of both IL-1 $\alpha$ and IL-1 $\beta$ by competitively blocking their binding to IL-1R1 and IL-1R2. Anakinra has been applied for a wide range of diseases including autoinflammatory diseases, non-cancer inflammatory diseases, and malignancies [150]. To date, no serious adverse effect of anakinra has been reported [151].

\section{Rilonacept}

Another is rilonacept (ril on' a sept), a soluble decoy receptor (Fig. 1). Rilonacept is a recombinant fusion protein consisting of the extracellular portion of human IL-1R1 and IL-1R3 fused with the Fc portion of human IgG1 [152-154]. Rilonacept binds to both IL- $1 \alpha$ and IL-1 $\beta$ with high affinity and inhibits the activity of both with a long-term inhibitory effect. Rilonacept was first approved by the FDA for the treatment of CAPS in 2008. Subcutaneous injection with a loading dose and a weekly injection of half the loading dose was administered [154]. There are no known severe adverse effects of rilonacept due to IL-1 signaling inhibition. These drugs could modulate the immune response. The most common side effects ( $>10 \%$ of treated patients) are inflammation of the upper respiratory tract or sinuses, headache, and redness at the injection site [154].

\section{Canakinumab}

The third is canakinumab (Fig. 1). Canakinumab, a specific human monoclonal IgG1 antibody targeting IL-1 $\beta$, is intravenously or subcutaneously infused to neutralize the bioactivity of human IL-1 $\beta[155,156]$. Canakinumab does not react with IL-1 $\alpha$ or IL-1R1. Therefore, canakinumab is a more specific inhibitor of IL-1 $\beta$, expected to have no effect on IL-1 $\alpha$-dependent host defense [154]. Early clinical trials established the administration of canakinumab every 2 weeks as safe and effective against several inflammatory diseases $[155,156]$.

\section{MABp 1}

There are several agents currently undergoing clinical trials. IL- $1 \alpha$ production is a very early step in the sterile inflammatory response at the center of the malignant phenotype that drives angiogenesis, tumor stromal remodeling, tumor invasiveness, metastasis, and cachexia [150, 157-159]. Thus, IL-1 $\alpha$ may be a particularly important target for the treatment of cancer. A neutralizing true human $\operatorname{IgG1\kappa }$ 
monoclonal antibody specific for human IL-1 $\alpha$, MABp1, has been developed, and it was well-tolerated with no dose-limiting toxicities or immunogenicity $[160,161]$ (Fig. 1). MABp1 treatment for patients with advanced colorectal cancer in a randomized, double-blind, placebocontrolled, phase 3 study revealed that MABp1 improved clinical performance in patients with advanced colorectal cancer [161]. MABp1 is a promising treatment for patients with hidradenitis suppurativa not eligible for the antiTNF- $\alpha$ antibody adalimumab [162].

\section{Gevokizumab}

Gevokizumab is an anti-IL-1 $\beta$ monoclonal antibody, IgG2, which improved glucose control and $\beta$-cell function in a diet-induced-obesity mouse model [163] and in the presence of IL-1 $\beta$-driven inflammatory diseases [164].

\section{LY2189102}

LY2189102 is a humanized monoclonal antibody (IgG4) that binds to IL-1 $\beta$ to neutralize its activity. Its affinity is comparatively high $(2.8 \mathrm{pmol} / \mathrm{L})$. Previous clinical studies evaluated not only its safety and pharmacokinetics but also its effects on RA (NCT00380744). Weekly treatment of T2D patients with LY2189103 for 3 months resulted in modest reductions in glycated hemoglobin and blood glucose [165]. Population pharmacokinetics (PK) of LY2189102 were characterized using data from 79 T2D subjects (Study H9C-MC-BBDK) who received 13 weekly subcutaneous doses of LY2189102 $(0.6,18$, and $180 \mathrm{mg})$ and 96 RA subjects (Study H9C-MC-BBDE) who received five weekly intravenous (IV) doses $(0.02-2.5 \mathrm{mg} / \mathrm{kg})$ [166]. No additional study has been reported.

\section{AMG 108}

AMG 108 is a fully human, IgG2 monoclonal antibody that binds to human IL-1R1, inhibiting the activity of IL-1 $\alpha$ and IL-1 $\beta$ [167]. Patients with osteoarthritis received placebo or AMG 108 subcutaneously (SC, 75 or $300 \mathrm{mg}$ ) or intravenously (IV, 100 or $300 \mathrm{mg}$ ) once every 4 weeks for 12 weeks or received placebo or $300 \mathrm{mg}$ AMG 108 SC, once every 4 weeks for 12 weeks; however, there was non-significant but numerically greater improvement in pain compared with the placebo group based on WOMAC pain scores [168]. AMG108 is now termed MEDI-8968 which has been studied in not only osteoarthritis, but also chronic obstructive pulmonary disease. In all cases, the benefit is limited $[168,169]$.

\section{EBI-005}

EBI-005 is a protein chimera of IL- $1 \beta$ and IL-1 receptor antagonists (IL-1Ra or anakinra). EBI-005 binds to IL-1R1 and inhibits IL-1 signaling and has been studied for the treatment of ocular surface inflammatory diseases [170].

\section{VX-765}

Since IL-1 $\beta$ is known to be processed and activated by caspase- 1 , caspase- 1 could be an indirect target for IL-1 $\beta$ signaling. To examine this, the highly selective caspase-1 inhibitor VX-765 was applied to a rat model of myocardial infarction (MI) and mouse model of $\mathrm{AD}[171,172]$.

\section{Applications of IL-1 blockade for diseases For autoinflammatory diseases}

The recombinant human IL-1-receptor antagonist anakinra is markedly effective against CAPS such as MWS, FCAS, and NOMID/CINCA. Weekly rilonacept treatment markedly improved the clinical symptoms of CAPS and normalized the levels of SAA in those at risk of developing amyloidosis [90, 153, 173, 174]. In several case reports of patients with FMF, anti-IL-1 treatment with anakinra, canakinumab, or rilonacept in colchicine-resistant patients was highly effective [175-178]. It was also reported that there was a rapid and lasting response of pyoderma gangrenosum to targeted treatment with anakinra in a patient with PAPA syndrome [179]. Anakinra and canakinumab therapies were also reported to be effective in patients with MKD/HIDS [180]. In the case of TRAPS, although TNF- $\alpha$ is considered to be mainly involved in clinical manifestations, marked improvement following IL-1 $\beta$ blockade occurred [112, 181]. An open-label, phase II study was reported whereby 19 patients with active recurrent or chronic TRAPS (19/20, 95\%; $95 \%$ CI $75.1 \%$ to $99.9 \%)$ achieved the primary efficacy endpoint. Canakinumab treatment for TRAPS rapidly improved the median time to clinical remission to 4 days (95\% CI 3 to 8 days) [182]. Skin findings also promptly improved upon anakinra treatment in a patient with DIRA [183]. Monotherapy involving canakinumab for the treatment of FMF has been reported [184]. A nationwide report on IL-1 treatment of patients with FMF revealed that 172 FMF patients (83 [48\%] female; mean age, 36.2 years [range, 18-68]) were included; the mean age at onset was 12.6 years (range, 1-48), and the mean colchicine dose was $1.7 \mathrm{mg} /$ day (range, 0.5-4.0). Anakinra was administered to 151 patients, and canakinumab was administered to 21 patients. Anti-IL-1 treatment was used in $84 \%$ of colchicine-resistant patients and $12 \%$ of amyloidosis patients. During the mean of 19.6 months of treatment (range, 6-98), the attack frequency per year was significantly decreased (from 16.8 to $2.4 ; P<0.001$ ), and symptoms of $42.1 \%$ of colchicine-resistant patients with FMF were ameliorated. In this study, the complete remission rate was $40 \%$ and inefficacy rate was $8 \%$ in patients treated with anakinra, whereas the complete remission rate was $65 \%$ and inefficacy rate was $6 \%$ for patients treated with canakinumab [185]. Although the response rates were not significant $\left(P=0.144\right.$ and $\left.\mathrm{X}^{2}=3.872606\right)$ in the study above [185], in our opinion, long-acting canakinumab may 
be more efficacious than anakinra, considering the necessity of daily subcutaneous anakinra injection because of its short half-time clearance of less than $12 \mathrm{~h}$ [185].

\section{For miscellaneous autoinflammatory diseases}

There are suspected etiologies of autoinflammatory disorders, but all lack a known genetic basis. In patients with adult-onset Still's disease (AOSD), anakinra monotherapy is significantly effective and has become the standard therapy, especially in prednisone-resistant patients. Commercially available anti-IL-1 agents (anakinra/Kineret ${ }^{\circ}$, canakinumab/ Ilaris ${ }^{\circ}$, or rilonacept/Arcalyst ${ }^{\circ}$ ) for patients with treatmentresistant AOSD are effective. Canakinumab and anakinra were also effective for patients with Schnitzler syndrome, an adult-onset autoinflammatory disease characterized by focal urticaria and systemic inflammation including fever with bone and muscle pain, in the first placebo-controlled study, and several clinical trials are currently ongoing [186-189].

\section{For autoimmune diseases}

IL-1 blockade therapy using anakinra is successful in patients with psoriatic arthritis, ankylosing spondylitis, and RA. On the other hand, its efficacy and safety are insufficient, precluding use for patients with systemic lupus erythematosus or Sjögren syndrome, and IL-1 $\beta$ inhibition using canakinumab had no effect on the decline in $\beta$-cell function after diabetes onset in patients with type 1 diabetes mellitus resulting from autoimmune-mediated $\beta$-cell loss [190-194]. As for RA, the enhanced release of other proinflammatory cytokines such as TNF- $\alpha$ and IL- 6 plays important roles in the inflamed synovium of RA patients [195]. In patients for whom TNF- $\alpha$ blockers are contraindicated, anakinra is effective in controlling the disease activity of RA and has been licensed for treatment at a dose of $100 \mathrm{mg} /$ day by subcutaneous injection every day $[196,197]$. Compared with anakinra, TNF inhibitors, such as the anti-TNF- $\alpha$ monoclonal antibody infliximab, or etanercept that fuse the TNF receptor to the end of the IgG1 antibody, dominate the field of biologics for RA because of the sense of well-being experienced by patients within hours of treatment [198]. Tocilizumab, a humanized anti-IL-6 receptor (IL-6R) monoclonal antibody, has also been shown to improve the symptoms of patients with RA [199]. However, those agents are associated with the risk of reactivating bacterial pathogens such as tuberculosis (TB) and malignancies [197]. Notably, no cases of TB reactivation were reported in 7964 RA patients after anakinra treatment, whereas 8 cases of TB reactivation were reported in 10,281 RA patients after tocilizumab treatment, and 7 and 10 cases of TB reactivation were reported in 2626 and 3167 RA patients after TNF-inhibitor treatment with golimumab and certolizumab pegol, respectively. This suggests the low risk of TB reactivation in RA patients treated with anti-IL-1 therapy [197].

\section{For infectious diseases}

Anakinra is safe and may be associated with a dose-related survival advantage in patients with septic shock syndrome complicated by acute respiratory distress syndrome, disseminated intravascular coagulation, and renal dysfunction, and subsequent secondary hemophagocytic lymphohistiocytosis (HLH), or macrophage-activating syndrome (MAS) [200, 201]. For sepsis with MAS, anakinra treatment led to significant improvements in hepatobiliary dysfunction and disseminated intravascular coagulation in patients $(65.4 \%$ anakinra vs. $35.3 \%$ placebo) and the 28 -day survival rate, with the hazard ratio for death being $0.28(0.11-0.71 ; p=$ 0.0071) for the treatment group on Cox regression. The data included 763 adults in the original study cohort, randomized to receive either anakinra or placebo [202].

\section{For metabolic syndromes}

IL-1 inhibition by anakinra, rilonacept, or canakinumab is efficacious for gout patients [203]. IL-1 plays a role in the progression of atherosclerosis as well [204]. In patients with a history of MI, canakinumab significantly reduced the high-sensitive serum CRP concentration from the baseline, as compared with a placebo, without affecting the LDL-cholesterol concentration. A 150-mg dose of canakinumab resulted in a significantly reduced risk of recurrent cardiovascular events compared with a placebo [205]. The inhibition of IL-1 with anakinra improved glycemia and the pancreatic $\beta$-cell function and reduced systemic inflammation [205]. Although IL-1 $\beta$ inhibition with canakinumab had similar effects on major cardiovascular events among those with and without diabetes, treatment over a median period of 3.7 years did not reduce incident diabetes [206]. The blockade of IL-1 with anakinra improved glycemia and the $\beta$-cell secretory function and reduced markers of systemic inflammation [104]. Anakinra also prevented transthyretin extracellular deposition in the sciatic nerve in a familial amyloidotic polyneuropathy mouse model [207].

\section{For ischemic diseases}

During ischemic disease, such as MI or cerebral infarction, or tissue injury, cell death by necrosis takes place and the IL-1 $\alpha$ precursor is released in sterile inflammation [208]. When there is no time for the synthesis of IL- $1 \alpha$, IL- $1 \alpha$ is ready to function as soon as it leaves the dying cell in the first few hours following tissue ischemia or injury [209]. In fact, animal studies showed that the inhibition of IL-1 is effective in limiting atherosclerosis and cardiovascular events and improving the symptoms of acute MI and ischemic stroke [210, 211]. Two pilot studies of IL-1 inhibition in ST-segment elevation MI revealed a reduced acute inflammatory response and favorable overall performance at the 3-month follow-up [212]. 


\section{For malignant diseases}

IL-1 $\beta$ is thought to play an important role in cancer invasiveness, progression, and metastases via inflammation in the tumor microenvironment. A further analysis in the Canakinumab Anti-inflammatory Thrombosis Outcomes Study (CANTOS), a randomized trial of the role of inhibition of IL-1 $\beta$ in atherosclerosis, revealed that anti-inflammatory therapy with canakinumab targeting the IL-1 $\beta$ innate immunity pathway could significantly reduce lung cancer mortality [213]. Moreover, treatment of patients with metastatic breast cancer-related with anakinra eliminates a systemic transcriptional signature of IL-1-associated inflammation in blood cells. The inflammatory signature in primary breast cancers identifies a subset of patients that could potentially benefit from IL-1 $\beta$-targeted therapies [129].

\section{Safety profiles}

Safety profiles of both anakinra and canakinumab were reported [214]. In this study, several clinical and

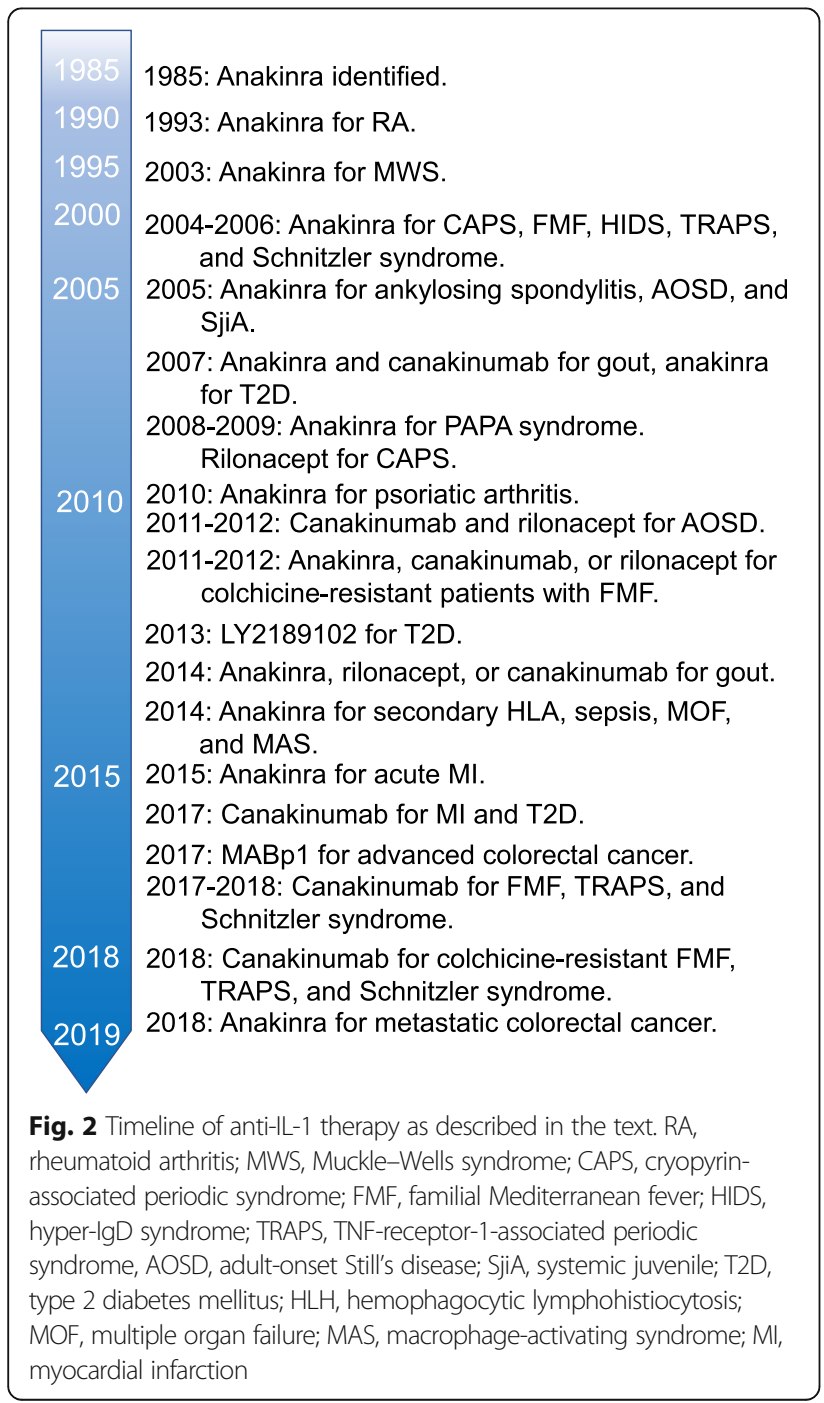

therapeutic data on patients treated with either anakinra or canakinumab were retrospectively analyzed. Four hundred and seventy-five patients participated; anakinra and canakinumab were prescribed in 421 and 105 treatment courses, respectively. Eighty-nine adverse events were recorded; 13 (14.61\%) were classified as serious adverse events during a mean follow-up of $24.39 \pm 27.04$ months. [214]. In addition, anakinra is applied to metastatic cancer. A trial involving metastatic colorectal cancer patients showed significantly increased survival when anakinra was added to standard chemotherapy for colorectal cancer and patients with HER2-negative breast cancer [129, 215]. The IL-1 blockade will reduce IL1-driven inflammation and immunosuppression that may contribute to the tumor metastatic

Table 2 Effective anti-IL-1 therapy for inflammatory diseases

Autoinflammatory diseases:

Cryopyrin-associated periodic syndrome (CAPS) [87, 88]

Familial Mediterranean fever (FMF) [95]

Pyogenic arthritis, pyoderma gangrenosum and acne syndrome (PAPA) [96]

NLRP12 autoinflammatory syndrome [97]

Tumor necrosis factor receptor-1-associated syndrome (TRAPS) [100]

Hyperimmunoglobulinemia D and periodic fever syndrome (HIDS)/ mevalonate kinase deficiency (MKD) [180]

Deficiency of the interleukin-1-receptor antagonist (DIRA) [183]

Autoimmune diseases:

Psoriatic arthritis [191]

Ankylosing spondylitis [192]

Rheumatoid arthritis (RA) [196]

Metabolic syndrome:

Gout [203]

Atherosclerosis [204]

Type 2 diabetes mellitus (T2D) [204]

Amyloidosis [207]

Neurodegenerative disease:

Alzheimer's disease (AD) [111]

Infections and inflammatory responses:

Septic shock syndrome [199]

Acute respiratory distress syndrome (ARDS) [199]

Disseminated intravascular coagulation (DIC) [199]

Hemophagocytic lymphohistiocytosis (HLH) [200]

Macrophage-activating syndrome (MAS) [200]

Ischemic diseases:

Myocardial infarction (MI) [209]

Stroke [209]

Malignant rumor:

Breast cancer [129] 
microenvironment [216]. The timeline of therapeutics is summarized in Fig. 2.

\section{Conclusions}

We described IL-1 as an important cytokine for not only inflammation related to cell injury but also homeostasis of cells, tissues, and organs in view of the general pathology. In addition, we also described recent expanding IL-1 signal-targeting for the treatment of diseases. Once the balance of IL-1 signaling is disrupted, it may markedly contribute to the pathogenesis of not only inflammatory disease, but also malignancies. IL-1-targeted biologics have been expanding, as there are no known serious adverse effects such as lymphoproliferative disorder or virus reactivation like TNF or IL-6-targeting therapies. Therefore, IL-1 is expected to become an attractive molecular target to treat a wide range of diseases such as autoinflammatory diseases, autoimmune diseases, infectious disease, metabolic syndromes, ischemic diseases, and malignant tumors $[217,218]$ (Table 2).

\section{Abbreviations}

AD: Alzheimer's disease; AOSD: Adult-onset Still's disease; APC: Antigenpresenting cell; CANTOS: Canakinumab Anti-inflammatory thrombosis Outcomes Study; CAPS: Cryopyrin-associated periodic syndrome; CARD: Caspaserecruitment domain; CINCA: Chronic infantile neurologic, cutaneous, and arthritis; CLR: C-type lectin receptor; CPPD: Calcium pyrophosphate dihydrate; CTL: Cytotoxic T lymphocyte; DAMP: Damage-associated molecular pattern; DC: Dendritic cell; DIRA: Deficiency of the

IL-1-receptor antagonist; ERK: Extracellular signal-regulated kinase; FCAS: Familial cold autoinflammatory syndrome; FDA: Food and Drug Administration; FMF: Familial Mediterranean fever; GSDMD: Gasdermin-D; HIDS: Hyperimmunoglobulinemia D and periodic fever syndrome; HLH: Hemophagocytic lymphohistiocytosis; IAPP: Islet amyloid polypeptide; ICE: IL-1 $\beta$-converting enzyme; IFN: Interferon; IKK: IK-B kinase; IL: Interleukin; IL-6 receptor: IL-6R; IL-18BP: Interleukin-18 binding protein; IL-1R1: IL-1 type 1 receptor; IL-1R2: IL-1 type 2 receptor; IL-1R3: IL-1 type 3 receptor; IL-1Ra: IL-1 receptor antagonist; IRAK: IL-1 receptor-associated kinase; JNK: CJun N-terminal kinase; LAF: Lymphocyte-activating factor;

LPS: Lipopolysaccharide; MAPK: Mitogen-activated protein kinase; MAS: Macrophage activation syndrome; MDP: Muramyl dipeptide MDSC: Myeloid-derived suppressor cell; MKD: Mevalonate kinase deficiency; MSU: Monosodium urate; MWS: Muckle-Wells syndrome; MyD88: Myeloid differentiation primary response protein 88; NEMO: NF-KB essential modulator; NK: Natural killer; NLR: NOD-like receptor; NLS: Nuclear localization sequence; NOMID: Neonatal-onset multisystem inflammatory disease; PAMP: Pathogen-associated molecular pattern; PAPA: Pyogenic arthritis, pyoderma gangrenosum, and acne; PAPASH: Pyogenic arthritis, acne, pyoderma gangrenosum and suppurative hidradenitis;

PASH: Pyoderma gangrenosum, acne, and suppurative hidradenitis; PRR: Pattern recognition receptor; PYD: Pyrin-domain; RA: Rheumatoid arthritis; RLR: RIG-I-like receptor; ROS: Reactive oxygen species; T2D: Type 2 diabetes mellitus; TAM: Tumor-associated macrophage; TB: Tuberculosis; Th1: T-helper cell type 1; TIR: Toll-IL-1 receptor; TLR: Toll-like receptor; TNF: Tumor necrosis factor; TRAF: TNF receptor-associated factor; TRAPS: TNF-receptor-1-associated syndrome; Treg: Regulatory T cell; VEGF: Vascular endothelial growth factor

\section{Acknowledgments}

Our colleague, Yuki Ito, died before the publication. This article is dedicated to her memory.

\section{Funding}

This work was supported by Grants-in-Aid for Scientific Research (B) (KAKENHI) (Grant Number: 17H04656) and Challenging Research (Exploratory)
(KAKENHI) (Grant Number: 17 K19685) from the Japan Society for the Promotion of Science (JSPS).

\section{Availability of data and materials \\ Not applicable.}

\section{Authors' contributions}

The manuscript was written by NK and JM, and all authors read and approved the final manuscript.

\section{Ethics approval and consent to participate}

Not applicable.

\section{Consent for publication}

Not applicable.

Competing interests

All authors declare that they have no competing interests.

\section{Publisher's Note}

Springer Nature remains neutral with regard to jurisdictional claims in published maps and institutional affiliations.

Received: 3 March 2019 Accepted: 7 May 2019

Published online: 06 June 2019

\section{References}

1. Spencer WG. Celsus: on medicine. , Vol. I Harvard University Press 1935, 73[Book III].

2. Rather LJ. Disturbance of function (functio laesa): the legendary fifth cardinal sign of inflammation, added by Galen to the four cardinal signs of Celsus. Bull N Y Acad Med. 1971:47:303-22.

3. Kumar V, Abbas AK, Aster JC. Robbins \& Cotran pathologic basis of disease. 9th ed. B.V. Amsterdam: Elsevier; 2015.

4. Hotamisligil GS. Inflammation and metabolic disorders. Nature. 2006;444: 860-7. https://doi.org/10.1038/nature05485.

5. Hotamisligil GS. Endoplasmic reticulum stress and the inflammatory basis of metabolic disease. Cell. 2010;140:900-17. https://doi.org/10.1016/..cell.2010.02.034.

6. Gregor MF, Hotamisligil GS. Inflammatory mechanisms in obesity. Annu Rev Immunol. 2011;29:415-45. https://doi.org/10.1146/annurev-immunol-031210-101322.

7. Janeway CA Jr. Approaching the asymptote? Evolution and revolution in immunology. Cold Spring Harb Symp Quant Biol. 1989;54:1-13.

8. Chovatiya R, Medzhitov R. Stress, inflammation, and defense of homeostasis. Mol Cell. 2014;54:281-8. https://doi.org/10.1016/j.molcel.2014.03.030.

9. Takeuchi O, Akira S. Pattern recognition receptors and inflammation. Cell. 2010;140:805-20. https://doi.org/10.1016/j.cell.2010.01.022.

10. Latz E, Miyake K. Editorial overview: special section: effects of endogenous immune stimulants: from a defence system against infection to a homeostatic mechanism linking metabolism with inflammation. Curr Opin Immunol. 2014;30:viii-x. https://doi.org/10.1016/j.coi.2014.09.002.

11. Poyet JL, Razmara M, Datta P, Zhang Z, Alnemri ES. The PYRIN-CARD protein ASC is an activating adaptor for caspase-1. Srinivasula SM, J Biol Chem. 2002;277:21119-22. https://doi.org/10.1074/jbc.C200179200.

12. Martinon F, Burns K, Tschopp J. The inflammasome: a molecular platform triggering activation of inflammatory caspases and processing of proll- $\beta$. Mol Cell. 2002;10:417-26.

13. Mason DR, Beck PL, Muruve DA. Nucleotide-binding oligomerization domain-like receptors and inflammasomes in the pathogenesis of nonmicrobial inflammation and diseases. J Innate Immun. 2012;4:16-30. https:// doi.org/10.1159/000334247.

14. Rathinam VA, Vanaja SK, Fitzgerald KA. Regulation of inflammasome signaling. Nat Immunol. 2012;13:333-42. https://doi.org/10.1038/ni.2237.

15. Ogawa Y. Homeostatic inflammation, an emerging concept. Endocr J. 2010; 57:657-8.

16. Miyake K, Kaisho T. Homeostatic inflammation in innate immunity. Curr Opin Immunol. 2014;30:85-90. https://doi.org/10.1016/j.coi.2014.08.003.

17. Hotamisligil GS. Inflammation, metaflammation and immunometabolic disorders. Nature. 2017;542:177-85. https://doi.org/10.1038/nature21363.

18. Medzhitov R. Origin and physiological roles of inflammation. Nature. 2008; 454:428-35. https://doi.org/10.1038/nature07201. 
19. Antonelli M, Kushner I. It's time to redefine inflammation. FASEB J. 31:178791. https://doi.org/10.1096/fj.201601326R.

20. Ballak DB, Stienstra R, Tack CJ, Dinarello CA, van Diepen JA. IL-1 family members in the pathogenesis and treatment of metabolic disease: focus on adipose tissue inflammation and insulin resistance. Cytokine. 2015;75:28090. https://doi.org/10.1016/j.cyto.2015.05.005

21. Dinarello CA. Immunological and inflammatory functions of the interleukin1 family. Annu Rev Immunol. 2009;27:519-50. https://doi.org/10.1146/ annurev.immunol.021908.132612.

22. Gery I, Gershon RK, Waksman BH. Potentiation of the T-lymphocyte response to mitogens. I. The responding cell. J Exp Med. 1972;136:128-42.

23. Rosenstreich DL, Vogel SN, Jacques AR, Wahl LM, Oppenheim JJ. Macrophage sensitivity to endotoxin: genetic control by a single codominant gene. J Immunol. 1978;121:1664-70.

24. Mizel SB. Biochemical and biological characterization of lymphocyteactivating factor (LAF) produced by the murine macrophage cell line, P388D. Ann N Y Acad Sci. 1979;332:539-49.

25. di Giovine FS, Duff GW. Interleukin 1: the first interleukin. Immunol Today. 1990;11:13-20.

26. Halliday WJ, Maluish A, Isbister WH. Detection of anti-tumour cell mediated immunity and serum blocking factors in cancer patients by the leucocyte adherence inhibition test. Br J Cancer. 1974;29:31-5.

27. Maluish A, Halliday WJ. Cell-mediated immunity and specific serum factors in human cancer: the leukocyte adherence inhibition test. J Natl Cancer Inst. 1974:52:1415-20.

28. Fujisawa T, Waldman SR, Yonemoto RH. Leukocyte adherence inhibition by soluble tumor antigens in breast cancer patients. Cancer. 1977:39:506-13.

29. Allavena P, Sica A, Solinas G, Porta C, Mantovani A. The inflammatory microenvironment in tumor progression: the role of tumor-associated macrophages. Crit Rev Oncol Hematol. 2008;66:1-9. https://doi.org/10.1016/ j.critrevonc.2007.07.004.

30. Chen L, Huang CF, Li YC, Deng WW, Mao L, Wu L, Zhang WF, Zhang L, Sun ZJ. Blockage of the NLRP3 inflammasome by MCC950 improves anti-tumor immune responses in head and neck squamous cell carcinoma. Cell Mol Life Sci. 2018;75:2045-58. https://doi.org/10.1007/s00018-017-2720-9.

31. Guo B, Fu S, Zhang J, Liu B, Li Z. Targeting inflammasome/LL-1 pathways for cancer immunotherapy. Sci Rep. 2016;6:36107. https://doi.org/10.1038/srep36107.

32. Dinarello C, Arend W, Sims J, Smith D, Blumberg H, O'Neill L, GoldbachMansky R, Pizarro T, Hoffman H, Bufler P, Nold M, Ghezzi P, Mantovani A, Garlanda C, Boraschi D, Rubartelli A, Netea M, van der Meer J, Joosten L, Mandrup-Poulsen T, Donath M, Lewis E, Pfeilschifter J, Martin M, Kracht M, Muehl H, Novick D, Lukic M, Conti B, Solinger A, Kelk P, van de Veerdonk F, Gabel C. IL-1 family nomenclature. Nat Immunol. 2010;11:973. https://doi. org/10.1038/ni1110-973.

33. Garlanda C, Dinarello CA, Mantovani A. The interleukin-1 family: back to the future. Immunity. 2013;39:1003-18. https:/doi.org/10.1016/j.immuni.2013.11.010

34. Lachman LB, Hacker MP, Handschumacher RE. Partial purification of human lymphocyte-activating factor (LAF) by ultrafiltration and electrophoretic techniques. J Immunol. 1977;119:2019-23.

35. Priestle JP, Schär HP, Grütter MG. Crystallographic refinement of interleukin $1 \beta$ at 2.0 A resolution. Proc Natl Acad Sci U S A. 1989;86:9667-71.

36. Graves BJ, Hatada MH, Hendrickson WA, Miller JK, Madison VS, Satow Y. Tructure of interleukin 1 at 2.7-A resolution. Biochemistry. 1990;29:2679-84.

37. Veerapandian B. Structure and function of interleukin-1, based on crystallographic and modeling studies. Biophys J. 1992;62:112-5. https://doi.org/10.1016/S00063495(92)81796-4.

38. Werman A, Werman-Venkert R, White R, Lee JK, Werman B, Krelin Y, Voronov E, Dinarello CA, Apte RN. The precursor form of IL-1a is an intracrine proinflammatory activator of transcription. Proc Natl Acad Sci U S A. 2004;101:2434-9.

39. Enya K, Hayashi H, Takii T, Ohoka N, Kanata S, Okamoto T, Onozaki K. The interaction with Sp1 and reduction in the activity of histone deacetylase 1 are critical for the constitutive gene expression of IL-1 alpha in human melanoma cells. J Leukoc Biol. 2008;83:190-9. https://doi.org/10.1189/jlb.0106008.

40. Kimura H, Inukai $Y$, Takii T, Furutani $Y$, Shibata $Y$, Hayashi H, Sakurada S, Okamoto T, Inoue J, Oomoto Y, Onozaki K. Molecular analysis of constitutive IL-1alpha gene expression in human melanoma cells: autocrine stimulation through NF-KB activation by endogenous IL-1a. Cytokine. 1998;10:872-9.

41. Gross O, Yazdi AS, Thomas CJ, Masin M, Heinz LX, Guarda G, Quadroni M, Drexler SK, Tschopp J. Inflammasome activators induce interleukin-1a secretion via distinct pathways with differential requirement for the protease function of caspase-1. Immunity. 2012;36:388-400. https://doi.org/ 10.1016/j.immuni.2012.01.018.

42. Chen CJ, Kono H, Golenbock D, Reed G, Akira S, Rock KL. Identification of a key pathway required for the sterile inflammatory response triggered by dying cells. Nat Med. 2007;13:851-6. https://doi.org/10.1038/nm1603.

43. Kim B, Lee Y, Kim E, Kwak A, Ryoo S, Bae SH, Azam T, Kim S, Dinarello CA. The interleukin-1a precursor is biologically active and is likely a key Alarmin in the IL-1 family of cytokines. Front Immunol. 2013;4:391. https://doi.org/10. 3389/fimmu.2013.00391.

44. March CJ, Mosley B, Larsen A, Cerretti DP, Braedt G, Price V, Gillis S, Henney CS, Kronheim SR, Grabstein K, Conlon PJ, Hopp TP, Cosman D. Cloning, sequence and expression of two distinct human interleukin-1 complementary DNAs. Nature. 1985;315:641-7.

45. Netea MG, van de Veerdonk FL, van der Meer JW, Dinarello CA, Joosten LA. Inflammasome-independent regulation of IL-1-family cytokines. Annu Rev Immunol. 2015;33:49-77. https://doi.org/10.1146/annurev-immunol-032414-112306.

46. Dinarello CA, Simon A, van der Meer JW. Treating inflammation by blocking interleukin-1 in a broad spectrum of diseases. Nat Rev Drug Discov. 2012;11: 633-52. https://doi.org/10.1038/nrd3800.

47. Robertson SE, Young JD, Kitson S, Pitt A, Evans J, Roes J, Karaoglu D, Santora L, Ghayur T, Liew FY, Gracie JA, McInnes IB. Expression and alternative processing of IL-18 in human neutrophils. Eur J Immunol. 2006;36:722-31. https://doi.org/10.1002/eji.200535402.

48. Mizutani H, Schechter N, Lazarus G, Black RA, Kupper TS. Rapid and specific conversion of precursor interleukin $1 \beta(\mathrm{IL}-1 \beta)$ to an active IL-1 species by human mast cell chymase. J Exp Med. 1991;174:821-5.

49. Dinarello CA, Cannon JG, Mier JW, Bernheim HA, LoPreste G, Lynn DL, Love RN, Webb AC, Auron PE, Reuben RC. Multiple biological activities of human recombinant interleukin 1. J Clin Invest. 1986;77:1734-9. https://doi.org/10. 1172/JCl112495.

50. Irmler M, Hertig S, MacDonald HR, Sadoul R, Becherer JD, Proudfoot A, Solari $\mathrm{R}$, Tschopp J. Granzyme A is an interleukin 1 beta-converting enzyme. J Exp Med. 1995;181:1917-22.

51. Hazuda DJ, Strickler J, Kueppers F, Simon PL, Young PR. Processing of precursor interleukin 1 $\beta$ and inflammatory disease. J Biol Chem. 1990;265:6318-22.

52. Cogswell JP, Godlevski MM, Wisely GB, Clay WC, Leesnitzer LM, Ways JP, Gray JG. NF-KB regulates IL-1 $\beta$ transcription through a consensus NF-KB binding site and a nonconsensus CRE-like site. J Immunol. 1994;153:712-23.

53. Eder C. Mechanisms of interleukin-1 $\beta$ release. Immunobiology. 2009;214:543-53.

54. Latz E, Xiao TS, Stutz A. Activation and regulation of the inflammasomes. Nat Rev Immunol. 2013;13:397-411. https://doi.org/10.1038/nri3452.

55. Lamkanfi M, Dixit VM. Mechanisms and functions of inflammasomes. Cell. 2014;157:1013-22. https://doi.org/10.1016/j.cell.2014.04.007.

56. Davis BK, Wen H, Ting JP. The inflammasome NLRs in immunity, inflammation, and associated diseases. Annu Rev Immunol. 2011;29:707-35. https://doi.org/10.1146/annurev-immunol-031210-101405.

57. Pétrilli V, Papin S, Dostert C, Mayor A, Martinon F, Tschopp J. Activation of the NALP3 inflammasome is triggered by low intracellular potassium concentration. Cell Death Differ. 2007;14:1583-9. https://doi.org/10.1038/sj. cdd.4402195.

58. Muñoz-Planillo R, Kuffa P, Martínez-Colón G, Smith BL, Rajendiran TM, Núñez $\mathrm{G} . \mathrm{K}^{+}$efflux is the common trigger of NLRP3 inflammasome activation by bacterial toxins and particulate matter. Immunity. 2013;38:1142-53. https:// doi.org/10.1016/j.immuni.2013.05.016.

59. Schmid-Burgk JL, Chauhan D, Schmidt T, Ebert TS, Reinhardt J, Endl E, Hornung V. A genome-wide CRISPR (clustered regularly interspaced short palindromic repeats) screen identifies NEK7 as an essential component of NLRP3 inflammasome activation. J Biol Chem. 2016;291:103-9. https://doi. org/10.1074/jbc.C115.700492.

60. He Y, Zeng MY, Yang D, Motro B, Núñez G. NEK7 is an essential mediator of NLRP3 activation downstream of potassium efflux. Nature. 2016;530:354-7. https://doi.org/10.1038/nature16959.

61. Shi H, Wang Y, Li X, Zhan X, Tang M, Fina M, Su L, Pratt D, Bu CH, Hildebrand S, Lyon S, Scott L, Quan J, Sun Q, Russell J, Arnett S, Jurek P, Chen D, Kravchenko W, Mathison JC, Moresco EM, Monson NL, Ulevitch RJ, Beutler B. NLRP3 activation and mitosis are mutually exclusive events coordinated by NEK7, a new inflammasome component. Nat Immunol. 2016;17:250-8. https://doi.org/10.1038/ni.3333.

62. Kayagaki N, Wong MT, Stowe IB, Ramani SR, Gonzalez LC, Akashi-Takamura S, Miyake K, Zhang J, Lee WP, Muszyński A, Forsberg LS, Carlson RW, Dixit VM. Noncanonical inflammasome activation by intracellular LPS 
independent of TLR4. Science. 2013;341:1246-9. https://doi.org/10.1126/ science.1240248.

63. Hagar JA, Powell DA, Aachoui Y, Ernst RK, Miao EA. Cytoplasmic LPS activates caspase-11: implications in TLR4-independent endotoxic shock. Science. 2013;341:1250-3. https://doi.org/10.1126/science.1240988.

64. Shi J, Zhao Y, Wang Y, Gao W, Ding J, Li P, Hu L, Shao F. Inflammatory caspases are innate immune receptors for intracellular LPS. Nature. 2014;514: 187-2. https://doi.org/10.1038/nature13683.

65. Schmid-Burgk JL, Gaidt MM, Schmidt T, Ebert TS, Bartok E, Hornung V. Caspase-4 mediates non-canonical activation of the NLRP3 inflammasome in human myeloid cells. Eur J Immunol. 2015;45:2911-7. https://doi.org/10. 1002/eji.201545523.

66. Chauhan D, Bartok E, Gaidt MM, Bock FJ, Herrmann J, Seeger JM, Broz P, Beckmann R, Kashkar H, Tait SWG, Müller R, Hornung V. BAX/BAK-induced apoptosis results in caspase-8-dependent IL-1 $\beta$ maturation in macrophages. Cell Rep. 2018;25:2354-2368.e5. https://doi.org/10.1016/j.celrep.2018.10.087.

67. Shi J, Zhao Y, Wang K, Shi X, Wang Y, Huang H, Zhuang Y, Cai T, Wang F, Shao F. Cleavage of GSDMD by inflammatory caspases determines pyroptotic cell death. Nature. 2015;526:660-5. https://doi.org/10.1038/nature15514.

68. Kayagaki N, Stowe IB, Lee BL, O'Rourke K, Anderson K, Warming S, Cuellar T, Haley B, Roose-Girma M, Phung QT, Liu PS, Lill JR, Li H, Wu J, Kummerfeld S, Zhang J, Lee WP, Snipas SJ, Salvesen GS, Morris LX, Fitzgerald L, Zhang Y, Bertram EM, Goodnow CC, Dixit VM. Caspase-11 cleaves gasdermin D for non-canonical inflammasome signalling. Nature. 2015;526:666-71. https:// doi.org/10.1038/nature15541.

69. He WT, Wan H, Hu L, Chen P, Wang X, Huang Z, Yang ZH, Zhong CQ, Han J. Gasdermin $D$ is an executor of pyroptosis and required for interleukin-1 $\beta$ secretion. Cell Res. 2015;25:1285-98. https://doi.org/10.1038/cr.2015.139.

70. Sborgi L, Rühl S, Mulvihill E, Pipercevic J, Heilig R, Stahlberg H, Farady CJ, Müller DJ, Broz P, Hiller S. GSDMD membrane pore formation constitutes the mechanism of pyroptotic cell death. EMBO J. 2016;35:1766-78. https:// doi.org/10.15252/embj.201694696

71. Aglietti RA, Estevez A, Gupta A, Ramirez MG, Liu PS, Kayagaki N, Ciferri C, Dixit VM, Dueber EC. GsdmD p30 elicited by caspase-11 during pyroptosis forms pores in membranes. Proc Natl Acad Sci U S A. 2016;113:7858-63. https://doi.org/10.1073/pnas.1607769113.

72. Ding J, Wang K, Liu W, She Y, Sun Q, Shi J, Sun H, Wang D-C, Shao F. Poreforming activity and structural autoinhibition of the gasdermin family. Nature. 2016;535:111-6. https://doi.org/10.1038/nature18590.

73. Liu X, Zhang Z, Ruan J, Pan Y, Magupalli VG, Wu H, Lieberman J. Inflammasomeactivated gasdermin $\mathrm{D}$ causes pyroptosis by forming membrane pores. Nature. 2016:535:153-8. https://doi.org/10.1038/nature18629.

74. Takács L, Kovacs EJ, Smith MR, Young HA, Durum SK. Detection of IL-1 alpha and LL-1 beta gene expression by in situ hybridization. Tissue localization of IL-1 mRNA in the normal C57BL/6 mouse. J Immunol. 1988;141:3081-95.

75. Dinarello CA. The interleukin-1 family: 10 years of discovery. FASEB J. 1994;8:1314-25.

76. Brikos C, Wait R, Begum S, O'Neill LA, Saklatvala J. Mass spectrometric analysis of the endogenous type I interleukin-1 (IL-1) receptor signaling complex formed after IL-1 binding identifies IL-1RAcP, MyD88, and IRAK-4 as the stable components. Mol Cell Proteomics. 2007;6:1551-9. https://doi. org/10.1074/mcp.M600455-MCP200.

77. Martin P, Palmer G, Vigne S, Lamacchia C, Rodriguez E, Talabot-Ayer D, Rose-John S, Chalaris A, Gabay C. Mouse neutrophils express the decoy type 2 interleukin-1 receptor (IL-1R2) constitutively and in acute inflammatory conditions. J Leukoc Biol. 2013:94:791-802. https://doi.org/10.1189//lb.0113035.

78. Shimizu K, Nakajima A, Sudo K, Liu Y, Mizoroki A, Ikarashi T, Horai R, Kakuta S, Watanabe T, Iwakura Y. IL-1 receptor type 2 suppresses collagen-induced arthritis by inhibiting IL-1 signal on macrophages. J Immunol. 2015;194: 3156-68. https://doi.org/10.4049/jimmunol.1402155.

79. Boraschi D, Tagliabue A. The interleukin-1 receptor family. Semin Immunol. 2013;25:394-407. https://doi.org/10.1016/.smim.2013.10.023.

80. Martin M, Böl GF, Eriksson A, Resch K, Brigelius-Flohé R. Interleukin-1induced activation of a protein kinase co-precipitating with the type I interleukin-1 receptor in T cells. Eur J Immunol. 1994;24:1566-71. https://doi. org/10.1002/eji.1830240717.

81. Croston GE, Cao Z, Goeddel DV. NF-KB activation by interleukin-1 (IL-1) requires an IL-1 receptor-associated protein kinase activity. J Biol Chem. 1995:270:16514-7.

82. Hopp TP. Evidence from sequence information that the interleukin-1 receptor is a transmembrane GTPase. Protein Sci. 1995:4:1851-9. https://doi. org/10.1002/pro.5560040920.
83. Weber A, Wasiliew P, Kracht M. Interleukin-1 (IL-1) pathway. Sci Signal. 2010; 3:cm1. https://doi.org/10.1126/scisignal.3105 cm1

84. Dunne A, O'Neill LA. The interleukin-1 receptor/Toll-like receptor superfamily: signal transduction during inflammation and host defense. Sci STKE. 2003;2003:re3. https://doi.org/10.1126/stke.2003.171.re3.

85. Sakurai $\mathrm{H}$. Targeting of TAK1 in inflammatory disorders and cancer. Trends Pharmacol Sci. 2012;33:522-30. https://doi.org/10.1016/j.tips.2012.06.007.

86. Sabio G, Davis RJ. TNF and MAP kinase signalling pathways. Semin Immunol. 2014;26:237-45. https://doi.org/10.1016/.jsmim.2014.02.009.

87. Hoffman HM, Mueller JL, Broide DH, Wanderer AA, Kolodner RD. Mutation of a new gene encoding a putative pyrin-like protein causes familial cold autoinflammatory syndrome and Muckle-Wells syndrome. Nat Genet. 2001; 29:301-5. https://doi.org/10.1038/ng756.

88. Aksentijevich I, Nowak M, Mallah M, Chae JJ, Watford WT, Hofmann SR, Stein L, Russo R, Goldsmith D, Dent P, Rosenberg HF, Austin F, Remmers EF, Balow JE Jr, Rosenzweig S, Komarow H, Shoham NG, Wood G, Jones J, Mangra N, Carrero H, Adams BS, Moore TL, Schikler K, Hoffman H, Lovell DJ, Lipnick R, Barron K, O'Shea JJ, Kastner DL, Goldbach-Mansky R. De novo CIAS1 mutations, cytokine activation, and evidence for genetic heterogeneity in patients with neonatal-onset multisystem inflammatory disease (NOMID): a new member of the expanding family of pyrinassociated autoinflammatory diseases. Arthritis Rheum 2002;46:3340-3348. doi: https://doi.org/10.1002/art.10688.

89. Feldmann J, Prieur AM, Quartier P, Berquin P, Certain S, Cortis E, TeillacHamel D, Fischer A, de Saint Basile G. Chronic infantile neurological cutaneous and articular syndrome is caused by mutations in CIAS1, a gene highly expressed in polymorphonuclear cells and chondrocytes. Am J Hum Genet. 2002;71:198-203.

90. Goldbach-Mansky R, Dailey NJ, Canna SW, Gelabert A, Jones J, Rubin BI, Kim HJ, Brewer C, Zalewski C, Wiggs E, Hill S, Turner ML, Karp Bl, Aksentijevich I, Pucino F, Penzak SR, Haverkamp MH, Stein L, Adams BS, Moore TL, Fuhlbrigge RC, Shaham B, Jarvis JN, O'Neil K, Vehe RK, Beitz LO, Gardner G, Hannan WP, Warren RW, Horn W, Cole JL, Paul SM, Hawkins PN, Pham TH, Snyder C, Wesley RA, Hoffmann SC, Holland SM, Butman JA, Kastner DL. Neonatal-onset multisystem inflammatory disease responsive to interleukin1 beta inhibition. N Engl J Med. 2006;355:581-92. https://doi.org/10.1056/ NEJMoa055137.

91. Gattorno M, Tassi S, Carta S, Delfino L, Ferlito F, Pelagatti MA, D'Osualdo A, Buoncompagni A, Alpigiani MG, Alessio M, Martini A, Rubartelli A. Pattern of interleukin-1 beta secretion in response to lipopolysaccharide and ATP before and after interleukin-1 blockade in patients with CIAS1 mutations. Arthritis Rheum. 2007;56:3138-48. https://doi.org/10.1002/art.22842.

92. Hoffman HM, Brydges SD. Genetic and molecular basis of inflammasomemediated disease. J Biol Chem. 2011;286:10889-96. https://doi.org/10.1074/ jbc.R110.135491.

93. Xu H, Yang J, Gao W, Li L, Li P, Zhang L, Gong YN, Peng X, Xi JJ, Chen S, Wang F, Shao F. Innate immune sensing of bacterial modifications of Rho GTPases by the Pyrin inflammasome. Nature. 2014;513:237-41. https://doi. org/10.1038/nature13449.

94. Cugno M, Borghi A, Marzano AV. PAPA, PASH and PAPASH syndromes: pathophysiology, presentation and treatment. Am J Clin Dermatol. 2017;18: 555-62. https://doi.org/10.1007/s40257-017-0265-1.

95. Chae JJ, Wood G, Masters SL, Richard K, Park G, Smith BJ, Kastner DL. The B30.2 domain of pyrin, the familial Mediterranean fever protein, interacts directly with caspase-1 to modulate IL-1 B production. Proc Natl Acad Sci U S A. 2006;103:9982-7. https://doi.org/10.1073/pnas.0602081103.

96. Shoham NG, Centola M, Mansfield E, Hull KM, Wood G, Wise CA, Kastner DL. Pyrin binds the PSTPIP1/CD2BP1 protein, defining familial Mediterranean fever and PAPA syndrome as disorders in the same pathway. Proc Natl Acad Sci U S A. 2003;100: 13501-6. https:/doi.org/10.1073/pnas.2135380100.

97. Borghini S, Tassi S, Chiesa S, Caroli F, Carta S, Caorsi R, Fiore M, Delfino L, Lasigliè D, Ferraris C, Traggiai E, Di Duca M, Santamaria G, D'Osualdo A, Tosca M, Martini A, Ceccherini I, Rubartelli A, Gattorno M. Clinical presentation and pathogenesis of cold-induced autoinflammatory disease in a family with recurrence of an NLRP12 mutation. Arthritis Rheum. 2011;63:830-9. https://doi.org/10.1002/art.30170.

98. Frenkel J, Rijkers GT, Mandey SH, Buurman SW, Houten SM, Wanders RJ, Waterham HR, Kuis W. Lack of isoprenoid products raises ex vivo interleukin-1 secretion in hyperimmunoglobulinemia $\mathrm{D}$ and periodic fever syndrome. Arthritis Rheum. 2002;46:2794-803. https://doi.org/10.1002/art.10550.

99. Ruiz Gomez A, Couce ML, Garcia-Villoria J, Torres A, Baña Souto A, Yagüe J, Vilaseca MA, Ribes A, Aróstegui Jl. Clinical, genetic, and therapeutic diversity 
in 2 patients with severe mevalonate kinase deficiency. Pediatrics. 2012;129: e535-9. https://doi.org/10.1542/peds.2010-2192.

100. Sacré K, Brihaye B, Lidove O, Papo T, Pocidalo MA, Cuisset L, Dodé C. Dramatic improvement following interleukin 1beta blockade in tumor necrosis factor receptor-1-associated syndrome (TRAPS) resistant to antiTNF-a therapy. J Rheumatol. 2008:35:357-8.

101. Aksentijevich I, Masters SL, Ferguson PJ, Dancey P, Frenkel J, van RoyenKerkhoff A, Laxer R, Tedgård U, Cowen EW, Pham TH, Booty M, Estes JD, Sandler NG, Plass N, Stone DL, Turner ML, Hill S, Butman JA, Schneider R, Babyn P, El-Shanti HI, Pope E, Barron K, Bing X, Laurence A, Lee CC, Chapelle D, Clarke Gl, Ohson K, Nicholson M, Gadina M, Yang B, Korman BD, Gregersen PK, van Hagen PM, Hak AE, Huizing M, Rahman P, Douek DC, Remmers EF, Kastner DL, Goldbach-Mansky R. An autoinflammatory disease with deficiency of the interleukin-1-receptor antagonist. N Engl J Med. 2009; 360:2426-37. https://doi.org/10.1002/art.30170.

102. Maedler K, Sergeev P, Ris F, Oberholzer J, Joller-Jemelka HI, Spinas GA, Kaiser N, Halban PA, Donath MY. Glucose-induced beta cell production of IL-1beta contributes to glucotoxicity in human pancreatic islets. J Clin Invest. 2002; 110:851-60. https://doi.org/10.1172/JCl15318.

103. Zhou R, Tardivel A, Thorens B, Choi I, Tschopp J. Thioredoxin-interacting protein links oxidative stress to inflammasome activation. Nat Immunol. 2010;11:136-40. https://doi.org/10.1038/ni.1831.

104. Böni-Schnetzler M, Boller S, Debray S, Bouzakri K, Meier DT, Prazak R, Kerr-Conte J, Pattou F, Ehses JA, Schuit FC, Donath MY. Free fatty acids induce a proinflammatory response in islets via the abundantly expressed interleukin-1 receptor I. Endocrinology. 2009;150:5218-29. https://doi.org/10.1210/en.2009-0543.

105. Masters SL, Dunne A, Subramanian SL, Hull RL, Tannahill GM, Sharp FA, Becker C, Franchi L, Yoshihara E, Chen Z, Mullooly N, Mielke LA, Harris J, Coll RC, Mills KH, Mok KH, Newsholme P, Nuñez G, Yodoi J, Kahn SE, Lavelle EC, O'Neill LA. Activation of the NLRP3 inflammasome by islet amyloid polypeptide provides a mechanism for enhanced IL-1 $\beta$ in type 2 diabetes. Nat Immunol. 2010;11:897-904.

106. Mandrup-Poulsen T. IAPP boosts islet macrophage IL-1 in type 2 diabetes. Nat Immunol. 2010;11:881-3. https://doi.org/10.1038/ni.1935.

107. Westwell-Roper CY, Ehses JA, Verchere CB. Resident macrophages mediate islet amyloid polypeptide-induced islet IL-1 $\beta$ production and $\beta$-cell dysfunction. Diabetes. 2014;63:1698-711. https://doi.org/10.2337/db13-0863.

108. Halle A, Hornung V, Petzold GC, Stewart CR, Monks BG, Reinheckel T, Fitzgerald KA, Latz E, Moore K, Golenbock DT. The NALP3 inflammasome is involved in the innate immune response to amyloid- $\beta$. Nat Immunol. 2008; 9:857-65. https://doi.org/10.1038/ni.1636.

109. Morikawa S, Kaneko N, Okumura C, Taguchi H, Kurata M, Yamamoto T, Osawa H, Nakanishi A, Zako T, Masumoto J. IAPP/amylin deposition, which is correlated with expressions of ASC and IL-1 $\beta$ in $\beta$-cells of Langerhans' islets, directly initiates NLRP3 inflammasome activation. Int J Immunopathol Pharmacol. 2018;32: 2058738418788749. https://doi.org/10.1177/2058738418788749.

110. Nakanishi A, Kaneko N, Takeda H, Sawasaki T, Morikawa S, Zhou W, Kurata M, Yamamoto T, Akbar SMF, Zako T, Masumoto J. Amyloid $\beta$ directly interacts with NLRP3 to initiate inflammasome activation: identification of an intrinsic NLRP3 ligand in a cell-free system. Inflamm Regen. 2018;38:27. https://doi.org/10.1186/s41232-018-0085-6.

111. Carter KW, Hung J, Powell BL, Wiltshire S, Foo BT, Leow YC, McQuillan BM, Jennens M, McCaskie PA, Thompson PL, Beilby JP, Palmer LJ. Association of interleukin-1 gene polymorphisms with central obesity and metabolic syndrome in a coronary heart disease population. Hum Genet. 2008;124 199-206. https://doi.org/10.1007/s00439-008-0540-6.

112. Gattorno M, Tassi S, Carta S, Delfino L, Ferlito F, Pelagatti MA, D'Osualdo A, Buoncompagni A, Alpigiani MG, Alessio M, Martini A, Rubartelli A. Pattern of interleukin-1 $\beta$ secretion in response to lipopolysaccharide and ATP before and after interleukin-1 blockade in patients with CIAS1 mutations. Arthritis Rheum. 2007:56:3138-48. https://doi.org/10.1002/art.22842.

113. Doherty TA, Brydges SD, Hoffman HM. Autoinflammation: translating mechanism to therapy. J Leukoc Biol. 2011;90:37-47. https://doi.org/10. 1189/jlb.1110616.

114. Roerink ME, Groen RJ, Franssen G, Lemmers-van de Weem B, Boerman OC, van der Meer JW. Central delivery of iodine-125-labeled cetuximab, etanercept and anakinra after perispinal injection in rats: possible implications for treating Alzheimer's disease. Alzheimers Res Ther. 2015;7:70. https://doi.org/10.1186/s13195-015-0149-7.

115. Prantner D, Darville T, Sikes JD, Andrews CW Jr, Brade H, Rank RG, Nagarajan UM. Critical role for interleukin-1 $\beta$ (IL-1 $\beta$ ) during Chlamydia muridarum genital infection and bacterial replication-independent secretion of IL-1beta in mouse macrophages. Infect Immun. 2009;77:5334-46. https://doi.org/10. 1128/IAl.00883-09.

116. Yoshimura A, Mori $\mathrm{H}$, Ohishi M, Aki D, Hanada T. Negative regulation of cytokine signaling influences inflammation. Curr Opin Immunol. 2003;15:704-8.

117. Schenk M, Fabri M, Krutzik SR, Lee DJ, Vu DM, Sieling PA, Montoya D, Liu PT, Modlin RL. Interleukin-1 $\beta$ triggers the differentiation of macrophages with enhanced capacity to present mycobacterial antigen to T cells. Immunology. 2014;141:174-80. https:/doi.org/10.1111/imm.12167.

118. Lipsky PE, Thompson PA, Rosenwasser $\sqcup$, Dinarello CA. The role of interleukin 1 in human B cell activation: inhibition of B cell proliferation and the generation of immunoglobulin-secreting cells by an antibody against human leukocytic pyrogen. J Immunol. 1983;130:2708-14.

119. Ben Aribia MH, Leroy E, Lantz O, Métivier D, Autran B, Charpentier B, Hercend T, Senik A. rlL 2-induced proliferation of human circulating NK cells and T lymphocytes: synergistic effects of IL 1 and IL 2. J Immunol. 1987;139:443-51.

120. Ben-Sasson SZ, Wang K, Cohen J, Paul WE. IL-1 $\beta$ strikingly enhances antigen-driven CD4 and CD8 T-cell responses. Cold Spring Harb Symp Quant Biol. 2013;78:117-24. https://doi.org/10.1101/sqb.2013.78.021246.

121. Hutton HL, Ooi JD, Holdsworth SR, Kitching AR. The NLRP3 inflammasome in kidney disease and autoimmunity. Nephrology (Carlton). 2016;21:736-44. https://doi.org/10.1111/nep.

122. Mantovani A, Allavena P, Sica A, Balkwill F. Cancer-related inflammation. Nature. 2008;454:436-44. https://doi.org/10.1038/nature07205.

123. Jin L, Yuan RQ, Fuchs A, Yao Y, Joseph A, Schwall R, Schnitt SJ, Guida A, Hastings HM, Andres J, Turkel G, Polverini PJ, Goldberg ID, Rosen EM. Expression of interleukin-1ß in human breast carcinoma. Cancer. 1997:80:421-34.

124. Pantschenko AG, Pushkar I, Anderson KH, Wang Y, Miller $\amalg$, Kurtzman SH, Barrows G, Kreutzer DL. The interleukin-1 family of cytokines and receptors in human breast cancer: implications for tumor progression. Int J Oncol. 2003;23:269-84.

125. Mantovani A. Cancer: an infernal triangle. Nature. 2007:448:547-8. https:// doi.org/10.1038/448547a.

126. Mantovani A, Barajon I, Garlanda C. IL-1 and IL-1 regulatory pathways in cancer progression and therapy. Immunol Rev. 2018;281:57-61. https://doi. org/10.1111/imr.12614.

127. Weichand B, Popp R, Dziumbla S, Mora J, Strack E, Elwakeel E, Frank AC, Scholich K, Pierre S, Syed SN, Olesch C, Ringleb J, Ören B, Döring C, Savai R, Jung $M$, von Knethen A, Levkau B, Fleming I, Weigert A, Brüne B. S1PR1 on tumor-associated macrophages promotes lymphangiogenesis and metastasis via NLRP3/IL-1ß. J Exp Med. 2017;214:2695-713. https://doi.org/ 10.1084/jem.20160392.

128. Kolb R, Phan L, Borcherding N, Liu Y, Yuan F, Janowski AM, Xie Q, Markan KR, Li W, Potthoff MJ, Fuentes-Mattei E, Ellies LG, Knudson CM, Lee MH, Yeung SJ, Cassel SL, Sutterwala FS, Zhang W. Obesity-associated NLRC4 inflammasome activation drives breast cancer progression. Nat Commun. 2016;7:13007. https:// doi.org/10.1038/ncomms13007.

129. Wu TC, Xu K, Martinek J, Young RR, Banchereau R, George J, Turner J, Kim Kl, Zurawski S, Wang X, Blankenship D, Brookes HM, Marches F, Obermoser G, Lavecchio E, Levin MK, Bae S, Chung CH, Smith JL, Cepika AM, Oxley KL, Snipes GJ, Banchereau J, Pascual V, O'Shaughnessy J, Palucka AK. IL1 receptor antagonist controls transcriptional signature of inflammation in patients with metastatic breast cancer. Cancer Res. 2018;78:5243-58. https://doi.org/10.1158/0008-5472. CAN-18-0413.

130. Sugawara S, Uehara A, Nochi T, Yamaguchi T, Ueda H, Sugiyama A, Hanzawa K, Kumagai K, Okamura H, Takada H. Neutrophil proteinase 3mediated induction of bioactive IL-18 secretion by human oral epithelial cells. J Immunol. 2001;167:6568-75.

131. Gu Y, Kuida K, Tsutsui H, Ku G, Hsiao K, Fleming MA, Hayashi N, Higashino K, Okamura H, Nakanishi K, Kurimoto M, Tanimoto T, Flavell RA, Sato V, Harding MW, Livingston DJ, Su MS. Activation of interferon-gamma inducing factor mediated by interleukin-1 beta converting enzyme. Science. 1997;275:206-9.

132. Ghayur T, Banerjee S, Hugunin M, Butler D, Herzog L, Carter A, Quintal L, Sekut L, Talanian R, Paskind M, Wong W, Kamen R, Tracey D, Allen H. Caspase-1 processes IFN-gamma-inducing factor and regulates LPS-induced IFN-gamma production. Nature. 1997;386:619-23. https://doi.org/10.1038/386619a0.

133. Dinarello CA, Novick D, Kim S, Kaplanski G. Interleukin-18 and IL-18 binding protein. Front Immunol. 2013;4:289. https://doi.org/10.3389/fimmu.2013.00289.

134. Nakamura K, Okamura H, Wada M, Nagata K, Tamura T. Endotoxin-induced serum factor that stimulates gamma interferon production. Infect Immun. 1989:57:590-5. 
135. Morel JC, Park CC, Woods JM, Koch AE. A novel role for interleukin-18 in adhesion molecule induction through NF-kB and phosphatidylinositol (PI) 3kinase-dependent signal transduction pathways. J Biol Chem. 2001;276: 37069-75.

136. Lee JK, Kim SH, Lewis EC, Azam T, Reznikov LL, Dinarello CA. Differences in signaling pathways by IL-1 beta and IL-18. Proc Natl Acad Sci U S A. 2004; 101:8815-20. https://doi.org/10.1073/pnas.0402800101.

137. Puren AJ, Fantuzzi G, Dinarello CA. Gene expression, synthesis, and secretion of interleukin 18 and interleukin 1 beta are differentially regulated in human blood mononuclear cells and mouse spleen cells. Proc Natl Acad Sci U S A. 1999;96:2256-61.

138. Micallef MJ, Ohtsuki T, Kohno K, Tanabe F, Ushio S, Namba M, Tanimoto T, Torigoe K, Fujii M, Ikeda M, Fukuda S, Kurimoto M. Interferon-gammainducing factor enhances $T$ helper 1 cytokine production by stimulated human T cells: synergism with interleukin-12 for interferon-gamma production. Eur J Immunol. 1996;26:1647-51. https://doi.org/10.1002/eji. 1830260736.

139. Bellora F, Castriconi R, Doni A, Cantoni C, Moretta L, Mantovani A, Moretta A, Bottino C. M-CSF induces the expression of a membrane-bound form of IL-18 in a subset of human monocytes differentiating in vitro toward macrophages. Eur J Immunol. 2012;42:1618-26. https://doi.org/10.1002/eji.201142173.

140. Nakamura S, Otani T, ljiri Y, Motoda R, Kurimoto M, Orita K. IFN-gammadependent and -independent mechanisms in adverse effects caused by concomitant administration of IL-18 and IL-12. J Immunol. 2000;164:3330-6.

141. Schleinitz N, Vély F, Harlé JR, Vivier E. Natural killer cells in human autoimmune diseases. Immunology. 2010;131:451-8. https://doi.org/10. 1111/j.1365-2567.2010.03360.x.

142. McKie EA, Reid JL, Mistry PC, DeWall SL, Abberley L, Ambery PD, Gil-Extremera B. A study to investigate the efficacy and safety of an anti-interleukin-18 monoclonal antibody in the treatment of type 2 diabetes mellitus. PLoS One. 2016;11:e0150018. https://doi.org/10.1371/journal.pone.0150018.

143. Novick D, Kim SH, Fantuzzi G, Reznikov LL, Dinarello CA, Rubinstein M Interleukin-18 binding protein: a novel modulator of the Th1 cytokine response. Immunity. 1999;10:127-36.

144. Guan Y, Zhang R, Peng Z, Dong D, Wei G, Wang Y. Inhibition of IL-18mediated myeloid derived suppressor cell accumulation enhances anti-PD1 efficacy against osteosarcoma cancer. J Bone Oncol. 2017;9:59-64. https:// doi.org/10.1016/j.jbo.2017.10.002.

145. Kiltz U, Kiefer D, Braun J, Schiffrin EJ, Girard-Guyonvarc'h C, Gabay C. Prolonged treatment with Tadekinig alfa in adult-onset Still's disease. Ann Rheum Dis. 2018. https://doi.org/10.1136/annrheumdis-2018-214496.

146. Canna SW, Girard C, Malle L, de Jesus A, Romberg N, Kelsen J, Surrey LF, Russo P, Sleight A, Schiffrin E, Gabay C, Goldbach-Mansky R, Behrens EM. Life-threatening NLRC4-associated hyperinflammation successfully treated with IL-18 inhibition. J Allergy Clin Immunol. 2017;139:1698-701. https://doi. org/10.1016/j.jaci.2016.10.022

147. Arend WP. Interleukin 1 receptor antagonist. A new member of the interleukin 1 family. J Clin Invest. 1991;88:1445-51. https://doi.org/10.1172/ JCI115453.

148. Arend WP, Joslin FG, Massoni RJ. Effects of immune complexes on production by human monocytes of interleukin 1 or an interleukin 1 inhibitor. J Immunol. 1985;134:3868-75.

149. Liao Z, Grimshaw RS, Rosenstreich DL. Identification of a specific interleukin 1 inhibitor in the urine of febrile patients. J Exp Med. 1984;159:126-36.

150. Dinarello CA. An expanding role for interleukin-1 blockade from gout to cancer. Mol Med. 2014;20(Suppl 1):S43-58. https://doi.org/10.2119/molmed. 2014.00232.

151. Jain S, Thongprayoon C, Espinosa RE, Hayes SN, Klarich KW, Cooper LT, Moder KG, Anavekar NS, Oh JK, Matteson EL. Effectiveness and safety of anakinra for management of refractory pericarditis. Am J Cardiol. 2015;116: 1277-9. https://doi.org/10.1016/j.amjcard.2015.07.047.

152. Goldbach-Mansky R, Shroff SD, Wilson M, Snyder C, Plehn S, Barham B, Pham TH, Pucino F, Wesley RA, Papadopoulos JH, Weinstein SP, Mellis SJ, Kastner DL. A pilot study to evaluate the safety and efficacy of the longacting interleukin-1 inhibitor rilonacept (interleukin-1 Trap) in patients with familial cold autoinflammatory syndrome. Arthritis Rheum. 2008:58:2432-42. https://doi.org/10.1002/art.23620.

153. Hoffman HM, Throne ML, Amar NJ, Sebai M, Kivitz AJ, Kavanaugh A Weinstein SP, Belomestnov P, Yancopoulos GD, Stahl N, Mellis SJ. Efficacy and safety of rilonacept (interleukin-1 Trap) in patients with cryopyrinassociated periodic syndromes: results from two sequential placebo- controlled studies. Arthritis Rheum. 2008;58:2443-52. https://doi.org/10. 1002/art.23687.

154. Dubois EA, Rissmann R, Cohen AF. Rilonacept and canakinumab. Br J Clin Pharmacol. 2011;71:639-41. https://doi.org/10.1111/j.1365-2125.2011.03958.x.

155. Church LD, McDermott MF. Canakinumab, a fully-human mAb against IL-1 for the potential treatment of inflammatory disorders. Curr Opin Mol Ther. 2009;11:81-9.

156. Aday AW, Ridker PM. Antiinflammatory therapy in clinical care: the CANTOS trial and beyond. Front Cardiovasc Med. 2018;5:62. https://doi.org/10.3389/ fcrm.2018.00062.

157. Matsuo Y, Sawai H, Ma J, Xu D, Ochi N, Yasuda A, Takahashi H, Funahashi H, Takeyama H. IL-1a secreted by colon cancer cells enhances angiogenesis: the relationship between IL-1a release and tumor cells' potential for liver metastasis. J Surg Oncol. 2009;99:361-7. https://doi.org/10.1002/jso.21245.

158. Matsuo Y, Sawai H, Ochi N, Yasuda A, Takahashi H, Funahashi H, Takeyama $H$, Guha S. Interleukin-1a secreted by pancreatic cancer cells promotes angiogenesis and its therapeutic implications. J Surg Res. 2009;153:274-81. https://doi.org/10.1016/j.jss.2008.04.040.

159. Voronov E, Shouval DS, Krelin Y, Cagnano E, Benharroch D, Iwakura Y, Dinarello CA, Apte RN. IL-1 is required for tumor invasiveness and angiogenesis. Proc Natl Acad Sci U S A. 2003;100:2645-50. https://doi.org/ 10.1073/pnas.0437939100.

160. Hong DS, Hui D, Bruera E, Janku F, Naing A, Falchook GS, Piha-Paul S, Wheler JJ, Fu S, Tsimberidou AM, Stecher M, Mohanty P, Simard J, Kurzrock R. MABp1, a first-in-class true human antibody targeting interleukin-1a in refractory cancers: an open-label, phase 1 dose-escalation and expansion study. Lancet Oncol. 2014;15:656-66. https://doi.org/10.1016/S14702045(14)70155-X

161. Hickish T, Andre T, Wyrwicz L, Saunders M, Sarosiek T, Kocsis J, Nemecek R, Rogowski W, Lesniewski-Kmak K, Petruzelka L, Apte RN, Mohanty P, Stecher M, Simard J, de Gramont A. MABp1 as a novel antibody treatment for advanced colorectal cancer: a randomised, double-blind, placebo-controlled phase 3 study. Lancet Oncol. 2017;18:192-201. https://doi.org/10.1016/ S1470-2045(17)30006-2.

162. Kanni T, Argyropoulou M, Spyridopoulos T, Pistiki A, Stecher M, Dinarello CA, Simard J, Giamarellos-Bourboulis EJ. MABp1 targeting IL-1a for moderate to severe hidradenitis suppurativa not eligible for adalimumab: a randomized study. J Invest Dermatol. 2018;138:795-801. https://doi.org/10.1016/j.jid.2017.10.030.

163. Owyang AM, Maedler K, Gross L, Yin J, Esposito L, Shu L, Jadhav J, Domsgen E, Bergemann J, Lee S, Kantak S. XOMA 052, an anti-IL-1 $\beta$ monoclonal antibody, improves glucose control and $\beta$-cell function in the diet-induced obesity mouse model. Endocrinology. 2010;151:2515-27. https://doi.org/10. 1210/en.2009-1124.

164. Peiró C, Lorenzo Ó, Carraro R, Sánchez-Ferrer CF. IL-1ß inhibition in cardiovascular complications associated to diabetes mellitus. Front Pharmacol. 2017:8:363. https://doi.org/10.3389/fphar.2017.00363.

165. Sloan-Lancaster J, Abu-Raddad E, Polzer J, Miller JW, Scherer JC, De Gaetano A, Berg JK, Landschulz WH. Double-blind, randomized study evaluating the glycemic and anti-inflammatory effects of subcutaneous LY2189102, a neutralizing IL-1 $\beta$ antibody, in patients with type 2 diabetes. Diabetes Care. 2013;36:2239-46. https://doi.org/10.2337/dc12-1835.

166. Bihorel S, Fiedler-Kelly J, Ludwig E, Sloan-Lancaster J, Raddad E. Population pharmacokinetic modeling of LY2189102 after multiple intravenous and subcutaneous administrations. AAPS J. 2014;16:1009-17. https://doi.org/10. 1208/s12248-014-9623-6.

167. Cardiel MH, Tak PP, Bensen W, Burch FX, Forejtova S, Badurski JE, Kakkar T, Bevirt T, Ni L, McCroskery E, Jahreis A, Zack DJ. A phase 2 randomized, double-blind study of AMG 108, a fully human monoclonal antibody to IL1R, in patients with rheumatoid arthritis. Arthritis Res Ther. 2010;12:R192. https://doi.org/10.1186/ar3163.

168. Cohen SB, Proudman S, Kivitz AJ, Burch FX, Donohue JP, Burstein D, Sun YN, Banfield C, Vincent MS, Ni L, Zack DJ. A randomized, double-blind study of AMG 108 (a fully human monoclonal antibody to IL-1R1) in patients with osteoarthritis of the knee. Arthritis Res Ther. 2011;13:R125. https://doi.org/10. 1186/ar3430.

169. Calverley PMA, Sethi S, Dawson M, Ward CK, Finch DK, Penney M, Newbold $P$, van der Merwe R. A randomised, placebo-controlled trial of anti-interleukin-1 receptor 1 monoclonal antibody MEDI8968 in chronic obstructive pulmonary disease. Respir Res. 2017;18:153s. https:/doi.org/10.1186/s12931-017-0633-7.

170. Kovalchin J, King B, Masci A, Hopkins E, Fry J, Hou J, Li C, Tenneson K, Weber S, Wolfe G, Collins K, Furfine ES. Preclinical development of EBI-005: 
an IL-1 receptor-1 inhibitor for the topical ocular treatment of ocular surface inflammatory diseases. Eye Contact Lens. 2018:44:170-81. https://doi.org/10. 1097/ICL.0000000000000414.

171. Yang XM, Downey JM, Cohen MV, Housley NA, Alvarez DF, Audia JP. The highly selective caspase-1 inhibitor VX-765 provides additive protection against myocardial infarction in rat hearts when combined with a platelet inhibitor. J Cardiovasc Pharmacol Ther. 2017;22:574-8. https://doi.org/10. 1177/1074248417702890.

172. Flores J, Noël A, Foveau B, Lynham J, Lecrux C, LeBlanc AC. Caspase-1 inhibition alleviates cognitive impairment and neuropathology in an Alzheimer's disease mouse model. Nat Commun. 2018;9:3916. https://doi. org/10.1038/s41467-018-06449-x.

173. Hawkins PN, Lachmann HJ, McDermott MF. Interleukin-1-receptor antagonist in the Muckle-Wells syndrome. N Engl J Med. 2003;348:2583-4 https://doi.org/10.1056/NEJM200306193482523.

174. Hoffman HM, Rosengren S, Boyle DL, Cho JY, Nayar J, Mueller JL, Anderson JP, Wanderer AA, Firestein GS. Prevention of cold-associated acute inflammation in familial cold autoinflammatory syndrome by interleukin-1 receptor antagonist. Lancet. 2004;364:1779-85. https://doi.org/10.1016/ S0140-6736(04)17401-1.

175. Calligaris L, Marchetti F, Tommasini A, Ventura A. The efficacy of anakinra in an adolescent with colchicine-resistant familial Mediterranean fever. Eur J Pediatr. 2008;167:695-6. https://doi.org/10.1007/s00431-007-0547-3.

176. Bilginer Y, Ayaz NA, Ozen S. Anti-IL-1 treatment for secondary amyloidosis in an adolescent with FMF and Behçet's disease. Clin Rheumatol. 2010;29:20910. https://doi.org/10.1007/s10067-009-1279-8.

177. Hashkes PJ, Spalding SJ, Giannini EH, Huang B, Johnson A, Park G, Barron KS, Weisman MH, Pashinian N, Reiff AO, Samuels J, Wright DA, Kastner DL, Lovell DJ. Rilonacept for colchicine-resistant or -intolerant familial Mediterranean fever: a randomized trial. Ann Intern Med. 2012;157:533-41. https://doi.org/10.7326/0003-4819-157-8-201210160-00003.

178. De Benedetti F, Gattorno M, Anton J, Ben-Chetrit E, Frenkel J, Hoffman HM, KonéPaut I, Lachmann HJ, Ozen S, Simon A, Zeft A, Calvo Penades I, Moutschen M, Quartier P, Kasapcopur O, Shcherbina A, Hofer M, Hashkes PJ, Van der Hilst J, Hara R, Bujan-Rivas S, Constantin T, Gul A, Livneh A, Brogan P, Cattalini M, Obici L, Lheritier K, Speziale A, Junge $\mathrm{G}$. Canakinumab for the treatment of autoinflammatory recurrent fever syndromes. N Engl J Med. 2018;378:1908-19. https:/doi.org/10.1056/ NEJMoa1706314.

179. Brenner M, Ruzicka T, Plewig G, Thomas P, Herzer P. Targeted treatment of pyoderma gangrenosum in PAPA (pyogenic arthritis, pyoderma gangrenosum and acne) syndrome with the recombinant human interleukin-1 receptor antagonist anakinra. Br J Dermatol. 2009;161:1199-201. https:/doi.org/10.1111/j. 1365-21332009.09404x

180. Galeotti C, Meinzer U, Quartier P, Rossi-Semerano L, Bader-Meunier B, Pillet $P$, Koné-Paut I. Efficacy of interleukin-1-targeting drugs in mevalonate kinase deficiency. Rheumatology (Oxford). 2012;51:1855-9. https://doi.org/10.1093/ rheumatology/kes097.

181. Simon A, Bodar EJ, van der Hilst JC, van der Meer JW, Fiselier TJ, Cuppen MP, Drenth JP. Beneficial response to interleukin 1 receptor antagonist in traps. Am J Med. 2004;117:208-10.

182. Gattorno M, Obici L, Cattalini M, Tormey V, Abrams K, Davis N, Speziale A, Bhansali SG, Martini A, Lachmann HJ. Canakinumab treatment for patients with active recurrent or chronic TNF receptor-associated periodic syndrome (TRAPS): an open-label, phase II study. Ann Rheum Dis. 2017;76:173-8. https://doi.org/10.1136/annrheumdis-2015-209031.

183. Schnellbacher C, Ciocca G, Menendez R, Aksentijevich I, Goldbach-Mansky R, Duarte AM, Rivas-Chacon R. Deficiency of interleukin-1 receptor antagonist responsive to anakinra. Pediatr Dermatol. 2013;30:758-60. https://doi.org/10. 1111/j.1525-1470.2012.01725.x.

184. Jesenak M, Hrubiskova K, Kapustova L, Kostkova M, Banovcin P. Canakinumab as monotherapy for treatment of familial Mediterranean fever - first report in Central and Eastern Europe region. Bratisl Lek Listy. 2018;119: 198-200. https://doi.org/10.4149/BLL_2018_036.

185. Akar S, Cetin P, Kalyoncu U, Karadag O, Sari I, Cinar M, Yilmaz S, Onat AM, Kisacik B, Erden A, Balkarli A, Kucuksahin O, Oner SY, Senel S, Tufan A, Direskeneli H, Oksuz F, Pehlivan Y, Bayindir O, Keser G, Aksu K, Omma A, Kasifoglu T, Unal AU, Yildiz F, Balci MA, Yavuz S, Erten S, Ozgen M, Sayarlıoglu M, Dogru A, Yildirim G, Oner FA, Tezcan ME, Pamuk ON, Onen F. Nationwide experience with off-label use of interleukin-1 targeting treatment in familial Mediterranean fever patients. Arthritis Care Res. 2018; 70:1090-4. https://doi.org/10.1002/acr.23446.
186. Feist E, Quartier P, Fautrel B, Schneider R, Sfriso P, Efthimiou P, Cantarini L, Lheritier K, Leon K, Karyekar CS, Speziale A. Efficacy and safety of canakinumab in patients with Still's disease: exposure-response analysis of pooled systemic juvenile idiopathic arthritis data by age groups. Clin Exp Rheumatol. 2018;36:668-75.

187. Fitzgerald AA, Leclerca SA, Yan A, Homik JE, Dinarello CA. Rapid responses to anakinra in patients with refractory adult-onset Still's disease. Arthritis Rheum. 2005;52:1794-803. https://doi.org/10.1002/art.21061.

188. Junge G, Mason J, Feist E. Adult onset Still's disease-the evidence that antiinterleukin-1 treatment is effective and well-tolerated (a comprehensive literature review). Semin Arthritis Rheum. 2017;47:295-302. https:/doi.org/ 10.1016/j.semarthrit.2017.06.006.

189. Krause K, Tsianakas A, Wagner N, Fischer J, Weller K, Metz M, Church MK, Maurer M. Efficacy and safety of canakinumab in Schnitzler syndrome: a multicenter randomized placebo-controlled study. J Allergy Clin Immunol. 2017;139:1311-20. https://doi.org/10.1016/j.jaci.2016.07.041.

190. Mertens M, Singh JA. Anakinra for rheumatoid arthritis: a systematic review. J Rheumatol. 2009;36:1118-25. https://doi.org/10.3899/jrheum.090074.

191. Jung N, Hellmann M, Hoheisel R, Lehmann C, Haase I, Perniok A, Hallek M, Rubbert A. An open-label pilot study of the efficacy and safety of anakinra in patients with psoriatic arthritis refractory to or intolerant of methotrexate (MTX). Clin Rheumatol. 2010;29:1169-73. https://doi.org/10.1007/s10067-010-1504-5.

192. Haibel H, Rudwaleit M, Listing J, Sieper J. Open label trial of anakinra in active ankylosing spondylitis over 24 weeks. Ann Rheum Dis. 2005;64:296-8.

193. Ramos-Casals M, Brito-Zerón P, Muñoz S, Soto MJ, BIOGEAS STUDY Group. A systematic review of the off-label use of biological therapies in systemic autoimmune diseases. Medicine (Baltimore). 2008;87:345-64. https://doi.org/ 10.1097/MD.0b013e318190f170.

194. Moran A, Bundy B, Becker DJ, DiMeglio LA, Gitelman SE, Goland R, Greenbaum CJ, Herold KC, Marks JB, Raskin P, Sanda S, Schatz D, Wherrett DK, Wilson DM, Krischer JP, Skyler JS, Type 1 Diabetes TrialNet Canakinumab Study Group, Pickersgill L, de Koning E, Ziegler AG, Böehm B, Badenhoop K, Schloot N, Bak JF, Pozzilli P, Mauricio D, Donath MY, Castaño L, Wägner A, Lervang HH, Perrild H, Mandrup-Poulsen T, AIDA Study Group. Interleukin-1 antagonism in type 1 diabetes of recent onset: two multicentre, randomised, double-blind, placebo-controlled trials. Lancet. 2013;381:190515. https://doi.org/10.1016/S0140-6736(13)60023-9.

195. Takeuchi T. Revolutionary change in rheumatoid arthritis management with biological therapy. Keio J Med. 2011;60:75-81.

196. Dinarello CA. Interleukin-1 in the pathogenesis and treatment of inflammatory diseases. Blood. 2011;117:3720-32. https://doi.org/10.1182/ blood-2010-07-273417

197. Cantini F, Niccoli L, Goletti D. Tuberculosis risk in patients treated with nonanti-tumor necrosis factor-a (TNF-a) targeted biologics and recently licensed TNF-a inhibitors: data from clinical trials and national registries. J Rheumatol Suppl. 2014;91:56-64. https://doi.org/10.3899/jrheum.140103.

198. Hess A, Axmann R, Rech J, Finzel S, Heindl C, Kreitz S, Sergeeva M, Saake M, Garcia M, Kollias G, Straub RH, Sporns O, Doerfler A, Brune K, Schett G. Blockade of TNF-a rapidly inhibits pain responses in the central nervous system. Proc Natl Acad Sci U S A. 2011;108:3731-6. https://doi.org/10.1073/ pnas.1011774108.

199. Nishimoto N, Hashimoto J, Miyasaka N, Yamamoto K, Kawai S, Takeuchi T, Murata N, van der Heijde D, Kishimoto T. Study of active controlled monotherapy used for rheumatoid arthritis, an IL-6 inhibitor (SAMURAI): evidence of clinical and radiographic benefit from an $\mathrm{x}$ ray reader-blinded randomised controlled trial of tocilizumab. Ann Rheum Dis. 2007;66:1162-7. https://doi.org/10.1136/ard.2006.068064.

200. Fisher CJ Jr, Slotman GJ, Opal SM, Pribble JP, Bone RC, Emmanuel G, Ng D, Bloedow DC, Catalano MA. IL-1RA Sepsis Syndrome Study Group. Initial evaluation of human recombinant interleukin-1 receptor antagonist in the treatment of sepsis syndrome: a randomized, open-label, placebo-controlled multicenter trial. Crit Care Med. 1994;22:12-21.

201. Rajasekaran S, Kruse K, Kovey K, Davis AT, Hassan NE, Ndika AN, Zuiderveen S, Birmingham J. Therapeutic role of anakinra, an interleukin-1 receptor antagonist, in the management of secondary hemophagocytic lymphohistiocytosis/sepsis/multiple organ dysfunction/macrophage activating syndrome in critically ill children. Pediatr Crit Care Med. 2014;15: 401-8. https://doi.org/10.1097/PCC.0000000000000078.

202. Shakoory B, Carcillo JA, Chatham WW, Amdur RL, Zhao H, Dinarello CA, Cron RQ, Opal SM. Interleukin-1 receptor blockade is associated with reduced mortality in sepsis patients with features of macrophage activation 
syndrome: reanalysis of a prior phase III trial. Crit Care Med. 2016;44:275-81. https://doi.org/10.1097/CCM.0000000000001402.

203. Schlesinger N. Anti-interleukin-1 therapy in the management of gout. Curr Rheumatol Rep. 2014;16:398. https://doi.org/10.1007/s11926-013-0398-z.

204. Ridker PM, Thuren T, Zalewski A, Libby P. Interleukin-1 $\beta$ inhibition and the prevention of recurrent cardiovascular events: rationale and design of the Canakinumab Anti-inflammatory Thrombosis Outcomes Study (CANTOS). Am Heart J. 2011;162:597-605. https://doi.org/10.1016/j.ahj.2011.06.012.

205. Ridker PM, Everett BM, Thuren T, MacFadyen JG, Chang WH, Ballantyne C, Fonseca F, Nicolau J, Koenig W, Anker SD, Kastelein JJP, Cornel JH, Pais P, Pella D, Genest J, Cifkova R, Lorenzatti A, Forster T, Kobalava Z, Vida-Simiti L, Flather M, Shimokawa H, Ogawa H, Dellborg M, Rossi PRF, Troquay RPT, Libby P, Glynn R. CANTOS trial group. Antiinflammatory therapy with canakinumab for atherosclerotic disease. N Engl J Med. 2017;377:1119-31. https//doi.org/10.1056/NEJMra1 108178.

206. Everett BM, Donath MY, Pradhan AD, Thuren T, Pais P, Nicolau JC, Glynn RJ, Libby P, Ridker PM. Anti-inflammatory therapy with canakinumab for the prevention and management of diabetes. J Am Coll Cardiol. 2018;71:2392401. https://doi.org/10.1016/j.jacc.2018.03.002.

207. Gonçalves NP, Vieira P, Saraiva MJ. Interleukin-1 signaling pathway as a therapeutic target in transthyretin amyloidosis. Amyloid. 2014;21:175-84. https://doi.org/10.3109/13506129.2014.927759.

208. Larsen CM, Faulenbach M, Vaag A, Vølund A, Ehses JA, Seifert B, MandrupPoulsen T, Donath MY. Interleukin-1-receptor antagonist in type 2 diabetes mellitus. N Engl J Med. 2007;356:1517-26. https://doi.org/10.1056/ NEJMoa065213.

209. Rock KL, Latz E, Ontiveros F, Kono $H$. The sterile inflammatory response. Annu Rev Immunol. 2010;28:321-42. https://doi.org/10.1146/annurevimmunol-030409-101311.

210. Cohen I, Rider P, Carmi Y, Braiman A, Dotan S, White MR, Voronov E, Martin MU, Dinarello CA, Apte RN. Differential release of chromatin-bound IL-1 discriminates between necrotic and apoptotic cell death by the ability to induce sterile inflammation. Proc Natl Acad Sci U S A. 2010;107:2574-9. https://doi.org/10.1073/pnas.0915018107.

211. Abbate A, Van Tassell BW, Biondi-Zoccai GG. Blocking interleukin-1 as a novel therapeutic strategy for secondary prevention of cardiovascular events. BioDrugs. 2012;26:217-33. https://doi.org/10.2165/11631570000000000-00000.

212. Abbate A, Kontos MC, Abouzaki NA, Melchior RD, Thomas C, Van Tassell BW, Oddi C, Carbone S, Trankle CR, Roberts CS, Mueller GH, Gambill ML, Christopher S, Markley R, Vetrovec GW, Dinarello CA, Biondi-Zoccai G. Comparative safety of interleukin-1 blockade with anakinra in patients with ST-segment elevation acute myocardial infarction (from the VCU-ART and VCU-ART2 pilot studies). Am J Cardiol. 2015;115:288-92. https://doi.org/10.1016/j.amjcard.2014.11.003.

213. Ridker PM, MacFadyen JG, Thuren T, Everett BM, Libby P, Glynn RJ, CANTOS Trial Group. Effect of interleukin-1 $\beta$ inhibition with canakinumab on incident lung cancer in patients with atherosclerosis: exploratory results from a randomised, double-blind, placebo-controlled trial. Lancet. 2017;390:1833-42. https://doi.org/ 10.1016/50140-6736(17)32247-X.

214. Sota J, Vitale A, Insalaco A, Sfriso P, Lopalco G, Emmi G, Cattalini M, Manna R, Cimaz R, Priori R, Talarico R, de Marchi G, Frassi M, Gallizzi R, Soriano A, Alessio M, Cammelli D, Maggio MC, Gentileschi S, Marcolongo R, La Torre F, Fabiani C, Colafrancesco S, Ricci F, Galozzi P, Viapiana O, Verrecchia E, Pardeo M, Cerrito L, Cavallaro E, Olivieri AN, Paolazzi G, Vitiello G, Maier A, Silvestri E, Stagnaro C, Valesini G, Mosca M, de Vita S, Tincani A, Lapadula G, Frediani B, De Benedetti F, lannone F, Punzi L, Salvarani C, Galeazzi M, Angotti R, Messina M, Tosi GM, Rigante D, Cantarini L. "Working Group" of Systemic Autoinflammatory Diseases of SIR (Italian Society of Rheumatology). Safety profile of the interleukin-1 inhibitors anakinra and canakinumab in real-life clinical practice: a nationwide multicenter retrospective observational study. Clin Rheumatol. 2018. https://doi.org/10. 1007/s10067-018-4119-x

215. Isambert N, Hervieu A, Rébé C, Hennequin A, Borg C, Zanetta S, Chevriaux $A$, Richard C, Derangère V, Limagne E, Blanc J, Bertaut A, Ghiringhelli F. Fluorouracil and bevacizumab plus anakinra for patients with metastatic colorectal cancer refractory to standard therapies (IRAFU): a single-arm phase 2 study. Oncoimmunology. 2018;7:e1474319. https://doi.org/10.1080/ 2162402X.2018.1474319.

216. Bent R, Moll L, Grabbe S, Bros M. Interleukin-1 Beta-a friend or foe in malignancies? Int J Mol Sci 2018;19:pii:E2155. doi: https://doi.org/10.3390/ ijms19082155.
217. Dinarello CA, Thompson RC. Blocking IL-1: interleukin 1 receptor antagonist in vivo and in vitro. Immunol Today. 1991;12:404-10. https://doi.org/10. 1016/0167-5699(91)90142-G.

218. Dinarello CA, van der Meer JW. Treating inflammation by blocking interleukin-1 in humans. Semin Immunol. 2013;25:469-84. https://doi.org/10. 1016/j.smim.2013.10.008
Ready to submit your research? Choose BMC and benefit from:

- fast, convenient online submission

- thorough peer review by experienced researchers in your field

- rapid publication on acceptance

- support for research data, including large and complex data types

- gold Open Access which fosters wider collaboration and increased citations

- maximum visibility for your research: over $100 \mathrm{M}$ website views per year

At BMC, research is always in progress.

Learn more biomedcentral.com/submissions 